\title{
Yılın Öğretmenleri: \\ Çalışmaları, Motivasyon Unsurları, Kişisel ve Mesleki Özellikleri
}

\author{
Doç.Dr. Serkan Ünsal \\ Kahramanmaraş Sütçü İmam Üniversitesi-Türkiye \\ serkan-unsal09@hotmail.com
}

\author{
Hasan İğde (Yüksek Lisans) \\ Kahramanmaraş Sütçü Imam Üniversitesi-Türkiye \\ hasanigde46@gmail.com
}

\begin{abstract}
Özet:
Bu araştırmanın amacı, yılın öğretmenlerinin yaptıkları çalışmaları, motivasyon unsurlarını, kişisel ve mesleki özelliklerini, yılın öğretmeni seçilmelerinin mesleki ve sosyal hayatlarına yansımalarını belirlemektir. Nitel araştırma yöntemiyle yürütülen araştırmada fenomenolojik desen kullanılmıştır. Araştırmanın çalışma gurubunu, Anadolu'nun bir ilinde yılın öğretmeni olarak seçilen sekiz öğretmen oluşturmuştur. Çalışma grubu ölçüt örnekleme yöntemine uygun olarak belirlenmiştir. Ölçüt olarak yılın öğretmeni seçilme alınmıştır. Araştırmada veriler, yarı yapılandırımış görüşme formu ile elde edilmiştir. Elde edilen verilerin analizinde içerik ve betimsel analiz kullanılmıştır. Araştırmada, yılın öğretmenlerinin toplumsal sorunlara duyarlı olma, empâti yapabilme, samimiyete önem verme, çocukları sevme, hoşgörülü olma, meraklı olma gibi kişisel özelliklere sahip olduğu; öğrencinin hayatına dokunma, fedâkar olma, mesleğini sevme, ögrenciye okul dışı zaman ayırma, dersi sevdirme, liderlik yapma, mesleki özerklik, mesleki gelişimine önem verme gibi mesleki özelliklere sahip olduğu sonucuna ulaşılmıştır. Ayrıca araştırmada, yılın öğretmenlerinin akademik, sosyal, kültürel ve sportif birçok faaliyet yaptığı sonucuna ulaşılmıştır.
\end{abstract}

Keywords: Öğretmen, Öğretmenlik mesleği, Öğretmenin etkisi, Yılın ögretmeni

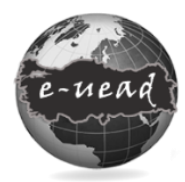

E-Uluslararası Eğitim

Araştırmaları Dergisi,

Cilt: 12, Sayı: 1, 2021, ss. 68-88

DOI: 10.19160/ijer.818654

Gönderim : 30.10 .2020 Kabul : 16.01 .2021

\section{Önerilen Atıf}

Ünsal, S., \& İğde, H. (2021). Yılın Öğretmenleri: Çalışmaları, Motivasyon Unsurları, Kişisel ve Mesleki Özellikleri, EUluslararası Eğitim Araştırmaları Dergisi, Cilt: 12, Sayı: 1, 2021, ss. 68-88, DOI: 10.19160/ijer.818654 


\section{GíRiş}

Öğretmenlerin üstlenmiş olduğu rol ve sorumlulukla dünden bugüne birey ve topluma birçok katkıda bulundukları, bugünden yarına da çok önemli katkılar sunacakları düşünülmektedir. Öğretmenin rolleri kültürlere/toplumlara, zamana ve şartlara göre değişim göstermektedir (Çetin ve Aydın, 2019). Öğretmenler, eğitim sisteminin niteliğini belirlemede, ideal insanı yetiştirmede dinamik ve stratejik değişkendir (Akcan ve Polat, 2016; Bozak, Özdemir ve Seraslan, 2016; Bozbayındır, 2019; Göker ve Gündüz, 2017; Hatipoğlu ve Kavas, 2016; İlğan ve Ceviz, 2019; Kozikoğlu ve Özcanlı, 2020). Öğretmenler, toplumların aynası (Erzen ve Epçaçan, 2018), kültürün öğrencilere aktarıcısı ve toplumun şekillenmesinin belirleyicisi (Özkan, 2017; Özkan ve Arslantaş, 2013; Ünsal ve Bağçeci, 2016), okulun kalbi, öğrenme-öğretme süreçlerinin de temel aktörüdür (Karadoğan, 2019; Şimşek ve Tuzluca 2015). Öğretmen, bireylerin hayatlarında önemli izler bırakarak onların davranışlarının oluşumunda etkin bir rol oynayan (Cerit, 2008) entelektüel bir yaşamın sahibi, zihinsel bir gücün temsilcisidir (Gönülaçar, 2016).

Öğretmenler, tutum ve davranışlarılla öğrencilerin akademik, sosyal ve duygusal gelişimini etkilemektedir (Sezer, 2018). Pedagojik açıdan öğretmenler, öğrenciler tarafından gözlenmekte ve rol model alınmaktadır (Akcan ve Polat, 2016). Öğrenciler ise öğretmenlerin söyleminden daha çok davranışlarıyla ilgilenmekte (Gönülaçar, 2016; Sarıbaş ve Babadağ, 2015), öğretmenin karakterinden, sevgisinden, şefkatinden, ahlaki bağılığı ve yetkinliğinden derinden etkilenmektedir (Kozikoğlu ve Özcanlı, 2020). Öğretmenlik mesleği, "tüm mesleklerin meslek adamını yetiştirmesi" bakımından diğer mesleklerden daha önemli ve farkı bir nitelik göstermektedir (Toprakçı, Bozpolat ve Buldur, 2010). Ancak henüz tam olarak da meslekleşememiştir (Toprakçı, 2009) Bu açıdan öğretmenler, mesleğinin öneminin farkında olmalı ve meslekten beklenilen rol ve sorumluluklarını yerine getirmelidir. Ancak öğretmenler kendilerinden beklenen rolleri, insan doğası gereği aynı düzeyde yerine getirememektedir (Yıldırım ve Öner, 2016). Bazı öğretmenler, sadece mevzuatta belirtilen görev ve sorumluluklarını yerine getirirken, bazıları ise mevzuatta belirtilen görev ve sorumluluklarını yerine getirmenin yansıra yaptığı işlerle ve yerine getirmiş olduğu farklı rollerle meslektaşları arasında öne çıkabilmektedir (Balyer, 2016). Bu öğretmenler için, ideal öğretmen (Başaran ve Baysal, 2016; Çelikten ve Can, 2003; Gençtürk, Akbaş ve Kaymakçı, 2012; Gültekin, 2015; Sarıtaş, 2013; Söylemez, 2018; Ulusoy, 2013), lider öğretmen (Balyer, 2016; Çeküç, 2008), iz bırakan öğretmen (Şimşek ve Tuzluca, 2015), etkili/başarılı öğretmen (Yıldııım ve Öner, 2016), etkili öğretmen (Aldan-Karademir ve Akgül, 2019; Bright, 2011; Özdemir Şerbet, 2012; Özkan ve Arslantaş, 2013; Sakız, 2016; Şahin, 2011), nitelikli öğretmen (Taşkaya, 2012), iyi öğretmen (Aypay, 2011; Işıktaş, 2015), idealist öğretmen (Can, Yıldırım, Bedir ve Atalmış, 2019), fark oluşturan öğretmen (Çetin ve Ünsal, 2020) gibi tanımlamalar kullanılmaktadır. Ayrıca MEB'de bu öğretmenler için yılın öğretmeni tanımlamasını kullanmaktadır. Bu tanımlamaya uygun öğretmenler, "24 Kasım Öğretmenler Günü" kutlama ve etkinlikleri kapsamında belirlenmektedir.

Belirlenme süreci 2019 yılında, Öğretmen Yetiştirme ve Geliştirme Genel Müdürlüğü (ÖYGM) koordinasyonunda, 27/05/2019 tarih ve 2019/8 sayılı 24 Kasım Öğretmenler Günü Kutlama Genelgesi'ne göre belirtilen esas ve usullere göre yapılmaktadır. Süreç sonunda Ankara'da düzenlenen Öğretmenler Günü kutlama ve etkinliklere, belirlenen yılın öğretmenleri davet edilmektedir. Yılın öğretmenlerini belirlemeye yönelik genelge esasları şöyledir;

1. MEB bünyesinde bulunan okul/kurumlarda eğitim-öğretim hizmetlerinde görev yapiyor olmak,

2. Öğretmenlik mesleğinde adaylıkta geçirilen süre dâhil en az 3 yıl hizmeti bulunmak,

3. Aylıktan kesme veya daha üst bir cezayı son 5 yıl içerisinde almamış olmak,

4. Bakanlıkça "24 Kasım Öğretmenler Günü" kapsamında düzenlenen etkinliklere il temsilcisi öğretmen olarak son 5 yıl içerisinde katılmamış olmak (ÖYGM, 2019).

Değerlendirmelere esas olan 2019/8 sayılı genelge ekinde bulunan başvuru ve değerlendirme formu, 5 tema olarak boyutlandırılmış ve her tema alt temalara ayrılarak yılın öğretmeni aday değerlendirme ölçütleri belirlenmiştir. Genelgede belirtilen değerlendirme temalarl; 
1. Öğretmenin eğitim-öğretim başarısı, mesleki tutum, değer ve davranışları,

2. Öğrenci gelişimine yönelik yaptıkları çalışmalar,

3. Öğretmenin akademik ve mesleki gelişim çalışmaları,

4. Öğretmenin kamuoyuna yansıyarak takdir görmüş çalışmaları (başarı öyküleri),

5. Temsil yeteneği (iletişim ve rol model olma) şeklindedir.

Belirtilen tema ve ölçütlere göre yapılan değerlendirme aşamalarında, her il temsilcisi öğretmen adayı için okul müdürü, ilçe ve il değerlendirme komisyonları ayrı ayrı puanlama yaparak, toplam puan ortalamasında en yüksek puanı alan öğretmen, il temsilcisi yılın öğretmeni olarak belirlenmektedir. II temsilcisi yılın öğretmenlerini belirleme aşamaları, Şekil 1'de sunulmuştur.

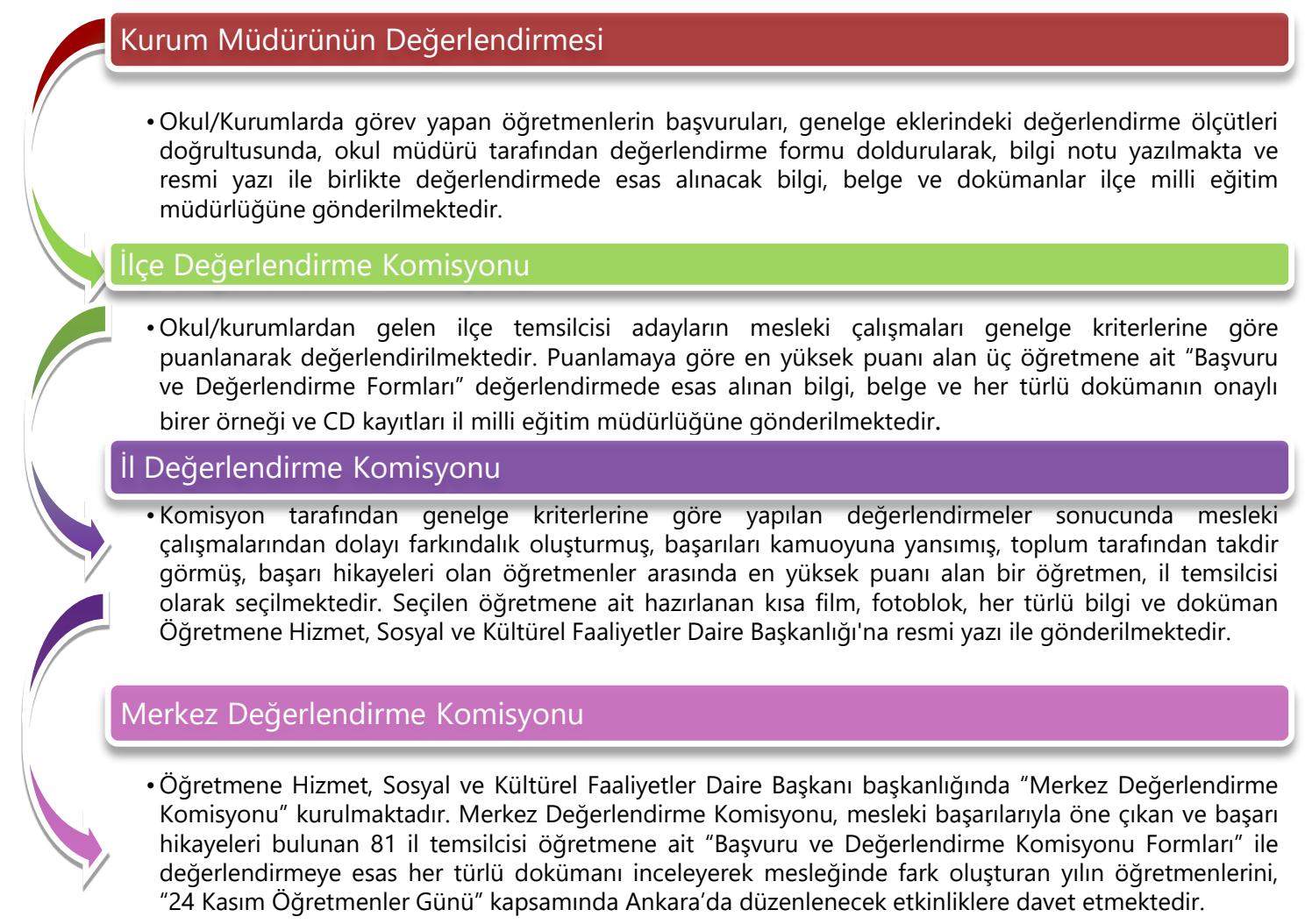

Şekil 1.Yılın öğretmenlerini belirleme aşamaları

MEB tarafından her yıl geliştirilen kriterlere göre yılın öğretmenleri belirlenmekle birlikte alanyazında yılın öğretmenlerini ele alan oldukça az çalışma bulunmaktadır. Eroğlu ve Özbek (2020) çalışmalarında yılın öğretmenlerini mesleki gelişimleri açısından konu edinmiştir. 2012 yılından itibaren her ilde düzenli olarak seçilen yılın öğretmenleri üzerine oldukça sınırlı sayıda çalışma yapılması, araştırmacılar tarafından bir eksiklik olarak görülmüştür. Bu çalışmanın belirtilen eksikliği gidermesi adına alanyazına katkı sağlayacağı beklenmektedir. Nitelikli öğretmen yetiştirmenin, her toplumda giderek daha da önemli bir konu haline geldiği (Caena, 2014; Dekker-Groen, Marieke, van der Schaaf ve Stokking, 2013) göz önünde bulundurularak, bu çalışmadan elde edilecek verilerin, nitelikli öğretmen yetiştirmede hizmet öncesinde sorumlu bulunan üniversitelere ve karar alıcılara önemli veri sunacağı düşünülmektedir. Ayrıca çalışmadan elde edilecek verilerin, mesleğini daha iyi yapma noktasında çaba ve arayış içerisinde olan öğretmenlere de bir yol gösterici olacağı düşünülmektedir. Bahsedilen önem doğrultusunda araştırmanın amacı, yılın öğretmenlerinin kişisel ve mesleki özelliklerini, yaptıkları çalışmaları, motivasyon unsurlarını, yılın öğretmeni olmanın mesleğe ve sosyal hayata yansımalarını belirlemektir. 


\section{YÖNTEM}

\section{Araştırma Modeli}

Çalışma, olgubilim deseninde yürütülmüş nitel bir araştırmadır. Nitel araştırmalar olgu, olay ya da davranışın nasıl ve neden ortaya çıktığı ile ilgilenir, bilgiler doğrudan birincil kaynaktan alınır. Nitel araştırmaların amacı, katııımcıları kendi bakış açılarına göre derinlemesine anlamaya çalışarak betimlemeler yapmaktır (Büyüköztürk, Kılıç-Çakmak, Akgün, Karadeniz ve Demirel, 2019; s. 253-254). Olgubilim çalışmaları, bir olgu ya da kavramla ilgili yaşanmış deneyimlerin ortak anlamını keşfeder (Creswell, 2020, s.79). Olgular, yaşadığımız dünyada olaylar, deneyimler, algılar, yönelimler, kavramlar ve durumlar gibi çeşitli biçimlerde de karşımıza çıkabilmektedir (Yıldıım ve şimşek, 2011, s. 72). Bu araştırmadaki olgu, "yılın öğretmeni olmak"tır.

\section{Çalışma Grubu}

Olgubilim araştırmalarında, katılımcıların olguyla ilişkili, olguyu yaşayan, olguyu açıklayabilecek, deneyim sahibi birincil kişiler olması önerilmektedir (Büyüköztürk vd., 2019; Yıldııım ve Şimşek, 2011). Bu araştırmada zengin veri setine ulaşabilmek ve olguyu en iyi açılayabilmek için amaçsal örnekleme yöntemlerinden ölçüt örnekleme (criterion sampling) yöntemi tercih edilmiştir (Büyüköztürk vd., 2019). Çalışma grubu için belirlenen ölçüt, yılın öğretmeni seçilmiş olmaktır. Yılın öğretmenlerinin demografik özellikleri Tablo $1^{\prime}$ de gösterilmiştir.

Tablo 1. Yılın Öğretmenlerinin Demografik Özellikleri

\begin{tabular}{llllll}
\hline Kod & Cinsiyet & Branş & Okul Türü & Mesleki Deneyim & Eğitim Durumu \\
\hline Ö1 & Erkek & Türkçe Öğretmenliği & Ortaokul & $11-20$ Yıl & Yüksek Lisans \\
Ö2 & Erkek & Türk Dili ve Edebiyatı & Lise & 21 Yıl Üzeri & Lisans \\
Ö3 & Erkek & Türk Dili ve Edebiyatı & Lise & 21 Yıl Üzeri & Yüksek Lisans \\
Ö4 & Erkek & Felsefe Öğretmenliği & Lise & $11-20$ Yıl & Lisans \\
Ö5 & Erkek & Türk Dili ve Edebiyatı & Lise & 21 Yıl Üzeri & Lisans \\
Ö6 & Erkek & Türk Dili ve Edebiyatı & Lise & 21 Yıl Üzeri & Yüksek Lisans \\
Ö7 & Erkek & Sınıf Öğretmenliği & İlkokul & $11-20$ Yıl & Doktora \\
Ö8 & Kadın & Türk Dili ve Edebiyatı & Lise & $11-20$ Yıl & Lisans \\
\hline
\end{tabular}

Araştırmanın amacına ve ölçütlere uygun olarak araştırmanın çalışma grubunu, Anadolu'nun bir ilinde bulunan III Milli Eğitim Müdürlüğü tarafından, 2012-2019 yılları arasında, farklı yıllarda yılın öğretmeni olarak belirlenen sekiz öğretmen oluşturmuştur. Katılımcı öğretmenlere etik kurallara uymak adına Ö1, Ö2, ..., Ö8 şeklinde kodlar verilmiştir.

Tablo 1 incelendiğinde, çalışma grubunda 1 kadın, 7 erkek yılın öğretmeni bulunduğu görülmektedir. Çalışma grubunun çoğunluğu Türk Dili ve Edebiyatı Öğretmeni (f:5) olup, diğerleri Türkçe, felsefe ve sınıf öğretmenidir. Çalışma grubundaki öğretmenlerin 6 'sı lise, 1'i ortaokul, 1'i ilkokulda görev yapmaktadır. Çalışma grubundaki öğretmenlerin 4'ü lisans, 3'ü yüksek lisans ve 1'i de doktora mezunudur. Mesleki kıdemleri ise 11-20 yıl arası (f:4) ile 21 yıl ve üzeri (f:4) olarak değişmektedir.

\section{Veri Toplama Araçları}

Veri toplama aracı olarak, görüşme tekniği kullanılmıştır. Görüşme, bireylerin gözlemlenen veya gözlemlenemeyen davranışlarının sebebini öğrenmek (Merriam, 2013), deneyimlerini ortaya çıkarmak, olaylardan ne şekilde etkilendiklerini tespit etmek (Patton, 2014), olguyla ilgili bilgi, düşünce ve tutumları belirlemek (Creswell, 2020) için gerçekleştirilmektedir. Verilerin toplanması amacıyla araştırmacılar tarafından geliştirilen yarı yapılandırılmış "Yılın Öğretmenleri Görüşme Formu (YÖGF)" kullanılmıştır. YÖGF hazırlanırken literatür taraması yapılmış (Akçadağ, 2017; 
Çetin ve Ünsal 2020; Yıldırım ve Öner 2016) ve Kahramanmaraş Sütçü İmam Üniversitesi Eğitim Fakültesi'nde öğretim üyesi iki uzmandan görüş alınmıştır.

\section{Verilerin Analizi}

Araştırmanın veri analizinde hem içerik hem de betimsel analizler yapılmıştır. Betimsel analiz, "Yılın öğretmenlerinin mesleki özellikleri nelerdir?" sorusundan elde edilen verilere yapılmıştır. Betimsel analiz yaklaşımına göre, elde edilen veriler önceden belirlenen temalara göre özetlenir ve yorumlanır (Kozikoğlu ve Senemoğlu, 2018). Betimsel analizde temalar, 2017 yılında güncellenen öğretmenlik mesleği genel yeterlikleri çerçevesinde belirtilen 3 yeterlik alanı, bu yeterlikler altında bulunan 11 yeterlik ve bu yeterliklere ilişkin 65 göstergeye göre belirlenmiştir. Diğer araştırma sorularından elde edilen verilere içerik analizi yapılmıştır. Iç̧erik analizinde veriler derinlemesine incelenerek kodlar belirlenir. Birbirleriyle ilişkili kodlar, aynı kavram altında bir araya getirilerek temalar oluşturulur (Berg ve Lune, 2019; Creswell, 2020; Merriam, 2013; Patton, 2014). Bu araştırmada katılımcıların verdiği cevaplar araştırmacılar tarafından ayrı ayrı incelenmiş sonrasında veriler kodlanmış ve ulaşılan kodlardan temalar oluşturulmuştur. Son aşamada, kod ve temalar sistematik olarak sunulmak amacıyla tablolar ya da şekiller oluşturularak yorumlanmıştır.

\section{Geçerlik ve Güvenirlik Çalışmaları}

Merriam (2013) nitel araştırmalarda geçerlik ve güvenirliğin sağlanması için öncelikle araştırmanın etik bir biçimde sürdürülmesi gerektiğini vurgulamıştır. Bu araştırmada geçerlik ve güvenirliğin sağlanması için etik kurallara uyulmuştur. Nitel araştırmalarda, nicel araştırmalardan farklı olarak geçerlik ve güvenirlik adına inandıııılık, aktarılabilirlik, tutarlılık ve teyit edilebilirlikle ilgili çalışmaların yapılması gerekmektedir (Lincoln ve Guba, 1985). Bu araştırmada, inandırıcılığı artırmaya yönelik, araştırmanın tüm aşaması ve katılımcılar hakkında ayrıntılı bilgilere yer verilmiş ve uzman görüşleri alınmıştır. Creswell'e (2020) göre, nitel çalışmalarda ayrıntılı bilgi verilmesi, açıklamaların inandırıcılığı noktasında okurun karar vermesine yardımcı olacaktır. Bu doğrultuda araştırmada aktarılabilirliği sağlama adına ayrıntılı açıklamalar yapıımış ve doğrudan alıntılara yer verilmiştir. Ayrıca okurlar için anlaşılır bir dil kullanılmış ve araştırma şekillerle desteklenmiştir. Tutarlııkta, araştırma verileriyle araştırma sonuçlarının birbiriyle tutarlı olması gerekir (Merriam, 2013; Yıldırım ve Şimşek, 2011). Araştırmacılar bu amaçla, araştırma yöntemini ve veri toplama araçlarını hazırlama ve uygulama süreçlerini, verileri nasıl toplayıp analiz ettiklerini, ulaştıkları sonuçları ayrıntılı bir şekilde açıklamıştır. Bunun yanında Creswell'e (2020) göre nitel araştırmalarda güvenirliği sağlamak adına veri setleri, birden fazla araştırmacı tarafından kodlanarak, kodlar arasındaki uyuma bakılması gerekmektedir. Kodlamaların farklı olduğu durumlarda araştırmacılar, kuramsal bilgilerden ve benzer çalışmalardan yararlanarak, kodların ne olacağına birlikte karar vermişlerdir. Bu doğrultuda teyit edilebilirlik adına araştırmanın verileri, bilgisayar ortamında dosyalanarak, istenildiği anda denetlenebilir hale getirilmiştir.

\section{BULGULAR}

Araştırmanın bu bölümünde, katılımcıların verdikleri cevaplardan elde edilen bulgular, araştırmanın yanıt aradığı soruların sırasına göre yer almaktadır.

\section{Yılın Öğretmenlerinin Kişisel Özellikleri}

Yılın öğretmenlerinin kişisel özellikleri; duyuşsal, sosyal ve bilişsel özellikler olarak alt temalara ayrılmıştır. Yılın öğretmenlerinin kişisel özellikleri Tablo 2'de sunulmuştur. Yılın öğretmenlerinin duyuşsal özellikleri; toplumsal sorunlara duyarlı olma $(f: 5)$, vatan evlatları yetiştirme arzusu $(f: 5)$, maneviyata önem verme $(f: 4)$, samimiyete önem verme $(f: 3)$, çocukları sevme $(f: 3)$, hoşgörülü olma $(f: 2)$, ihtiyaca duyarlı olma $(f: 2)$, dürüst olma $(f: 1)$ ve duygusal olma $(f: 1)$ şeklindedir. 
Tablo 2. Yılın Öğretmenlerinin Kişisel Özellikleri

\begin{tabular}{|c|c|c|c|c|}
\hline Tema & Alt Tema & Kodlar & $f$ & Katılımcılar \\
\hline \multirow{21}{*}{ 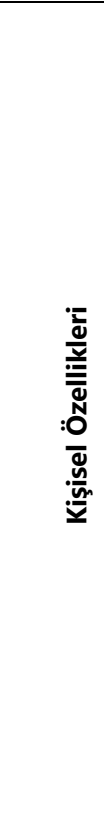 } & \multirow{9}{*}{ Duyuşsal Özellikleri } & Toplumsal sorunlara duyarlı olma & 5 & Ö4, Ö5, Ö6, Ö7, Ö8 \\
\hline & & Vatan evlatları yetiştirme arzusu & 5 & Ö2, Ö5, Ö6, Ö7, Ö8 \\
\hline & & Maneviyata önem verme & 4 & Ö2, Ö4, Ö5, Ö6 \\
\hline & & Samimiyete önem verme & 3 & Ö1, Ö2, Ö5 \\
\hline & & Çocukları sevme & 3 & Ö1, Ö4, Ö7 \\
\hline & & Hoşgörülü olma & 2 & Ö1, Ö4 \\
\hline & & İhtiyaca duyarlı olma & 2 & Ö5, Ö8 \\
\hline & & Dürüst olma & 1 & Ö2 \\
\hline & & Duygusal olma & 1 & Ö7 \\
\hline & \multirow{5}{*}{ Sosyal Özellikleri } & İşbirliği yapma & 4 & Ö3, Ö5, Ö6, Ö7 \\
\hline & & Empâti yapma & 4 & Ö4, Ö5, Ö7, Ö8 \\
\hline & & Güçlü iletişim becerilerine sahip olma & 3 & Ö1, Ö4, Ö8 \\
\hline & & Güleryüzlü olma & 1 & Ö4 \\
\hline & & Teşkilatçılık & 1 & Ö6 \\
\hline & \multirow{7}{*}{ Bilişsel Özellikleri } & Problem çözücü olma & 3 & Ö1, Ö4, Ö5 \\
\hline & & Kendi özelliklerinin farkında olma & 2 & Ö4, Ö5 \\
\hline & & Verilen görevi tamamlama & 2 & Ö4, Ö8 \\
\hline & & Öğrenme arzusunda bir merak & 2 & Ö3, Ö7 \\
\hline & & Planlı, programlı olma & 1 & Ö4 \\
\hline & & İyi bir dinleyici olma & 1 & Ö5 \\
\hline & & Çalışkan olma & 1 & Ö8 \\
\hline
\end{tabular}

Duyuşsal özellikler alt temasında, toplumsal sorunlara duyarlı olmaları ile ilgili Ö6'nın görüşü; "Kuru kuruya bir faaliyet değil, toplumumuzdaki bir eksikliği görüp, kalıcı bir şeyle nasıl yapılabilir?" şeklindedir. Vatan evlatları yetiştirme arzusu ile ilgili Ö2'nin görüşü; "Vatan evlatları yetiştirebilmenin samimi gayreti." şeklindedir. Maneviyata önem verme ile ilgili Ö6'nın görüşü; "Bendeki en büyük etkenlerden birisi, dünyaya geliş amacındaki büyük duyarlılık. Hem bu dünya hem öbür dünya noktasında, bu dünyanın öbür dünyanın tarlası olması noktasında bir duyarlılk." şeklindedir. Samimiyete önem verme ile ilgili Ö2'nin görüşü; "Onlara sunduğum derslerde ve eğitim amaçlı konuşmalarımda bütün ifadelerime samimiyetimin rengini kattım." şeklindedir. Çocukları sevme ile ilgili Ö7'nin görüşü; "Mesleği sevme, çocuğu sevme, işi sevme bunların hepsi bir araya gelmezse yani o duygular birleşmezse memurluktan öteye geçmez." şeklindedir. Hoşgörülü olmaları ile ilgili Ö1'in görüşü; "Hiçbir öğrenciye düşman değilimdir, asla kötülük beslemem, benim için hepsi değerlidir, kıymetlidir, hata yapar ve düzeltir diye düşünürüm." şeklindedir. İhtiyaca duyarlı olmaları ile ilgili Ö5'in görüşü; "Yoksul bir aileden olmam, ihtiyaç olduğunda o ihtiyaca cevap verme hissini bende öne çıkartıyor." şeklindedir.

Yılın öğretmenlerinin sosyal özellikleri; işbirliği yapma (f:4), empâti yapma (f:4), güçlü iletişim becerilerine sahip olma ( $f: 3)$, güler yüzlü olma ( $f .1)$ ve teşkilatçıllık ( $f .1)$ şeklindedir

Sosyal özellikler alt temasında, işbirliğine önem vererek ekip çalışmaları yapmaları ile ilgili Ö6'nın görüşü; "Arkadaş gruplarıyla, ekip ruhuyla çalışmayı seven birisiyim, arkadaşlarla birlikte, ferdi çalışmanın ötesinde başarıyı getirdiğine inanan birisiyim." şeklindedir. Empâti yapmaları ile ilgili Ö7'nin görüşü; "Doğrusu empâti kurmayı çok rahat yapabildiğim için, karşımdaki insanı önce yakınsarım, sonra empâtisini yaparım, daha sonra onunla ilgili duygu geliştiririm." şeklindedir. Güçlü iletişim becerilerine sahip olmaları ile ilgili Ö4'ün görüşü; "Mesleğe başladığım ilk günden itibaren iletişimi kuvvetli biri oldum." şeklindedir. Teşkilatçılık ile ilgili ise Ö6'nın görüşü; "Bizim en büyük özelliklerimizden bir tanesi, Türk vatandaşlarının diyelim, teşkilatçılığı. Çeşitli dernek ve vakıf teşkilatlarıyla şehrimizin güzel tarihi yerlerini geziyoruz, spor yapıyoruz, kamplar yapıyoruz, işte ne diyelim birçok sosyal etkinlik, kitap okuma grupları, kitap kritikleri yani sosyal etkinlikler her türlü mesela; ülke temsilciliği, ülke buluşmaları yapıyoruz, ülke yemekleri, ülke milli günleri yapıyoruz şu an böyle." şeklindedir.

Yılın öğretmenlerinin bilişsel özellikleri; problem çözücü olma ( $f .3)$, kendi özelliklerinin farkında olma (f.2), verilen görevi tamamlama (f.2), öğrenme arzusunda bir merak $(f .2)$, planlı, programlı olma $(f .1)$, iyi bir dinleyici olma $(f .1)$, çalışkan olma şeklindedir. 
Bilişsel özellikler alt temasında, problem çözücü ve çözümün parçası olmaları ile ilgili Ö1'in görüşü; "Öğrencilerin ... problemlerini çözeceğimize inanmıştık." şeklindedir. Kendi özelliklerinin farkında olmaları ile ilgili Ö4'ün görüşü; "Kişi zaten kendini tanımlamalı, tanırsa ancak hayatta başarılı olabileceğini düşünüyorum." şeklindeyken, kendilerine verilen görevleri yerine getirmeleri ile ilgili Ö8'in görüşü; "Yarım bırakmak istemiyorum bir işi." şeklindedir. Öğrenme arzusu ile ilgili Ö7'nin görüşü; "Kişisel olarak öğrenme açlı̆ımı düşünebilirsiniz, çünkü öğrenmeyi hiç bir zaman bırakmam, her zaman öğrenmeye çalışırım, kendimi asla yeterli görmem, öğrendiklerimi de güncellemeye çalışırım." şeklindedir. Planlı, programlı olma ile ilgili Ö4'ün görüşü; "Planlı, programlı yaşarım, hiç bir şeyi çok tesadüfe bırakmam." şeklindeyken, iyi bir dinleyici olma ile ilgili Ö5; "İyi bir dinleyici olmam öğrencilerimde daha fazla etki bırakıyor." şeklinde, çalışkan olma ile ilgili ise Ö8; "Çalışkanım, işimi layıkıyla yapmaya çalışıyorum." şeklinde görüş belirtmiştir.

\section{Yılın Öğretmenlerinin Mesleki Özellikleri}

Yılın öğretmenlerinin mesleki özellikleri; mesleki bilgi, mesleki beceri, mesleki tutum ve değerler olarak alt temalara ayrılmıştır. Yılın öğretmenlerinin mesleki özellikleri Tablo 3'te sunulmuştur.

Yılın öğretmenlerinin mesleki bilgi özellikleri, alan hâkimiyeti $(f .4)$ şeklindedir. Alanlarına hâkim olmaları ile ilgili Ö5; "Alanıma hâkim olmaya çalısııım." şeklindeki ifadesiyle görüşünü belirtmiştir.

Yılın öğretmenlerinin mesleki beceri özellikleri; öğrencilerin hayatına dokunarak olumlu izler bırakmaları (f.8), bilgiye duygu katarak dersi sevdirmeleri (f.6), öğretmen liderler olmaları $(f .5)$, mesleki özerkliğe yatkın olmaları $(f .5)$, öğrencileri takdir ederek cesaretlendirmeleri ( $f .4)$, öğrenci merkezli öğretim yapmaları $(f .4)$, öğrencilere empâti yaptırmaları $(f .3)$, farklı yöntem ve teknik kullanmaları $(f: 2)$, derslerini işlerken hayatın içerisinden örneklerle güncel bağlantılar kurmaları $(f: 2)$ şeklindedir.

Mesleki beceri alt temasında, öğrencilerin hayatına dokunarak olumlu izler bırakmaları ile ilgili Ö4'ün görüşü; "Klasik yöntem ve metotların haricinde çocukların hayatına dokunmaya çalıştım." şeklindedir. Öğrencilere dersi sevdirmeleri ile ilgili Ö2'nin görüşü; "Siz kendinizi derse konsantre ederseniz ögrenci de size konsantre oluyor, sesinizin rengini ortaya koyacak olan duyguyu bunlara dahil ederseniz, öğrenci dudaklarınızdan dökülen hiç bir ifadeyi kaçırmak istemez, tabii böyle olunca edebiyat dersi de olduğu için zaman ışıklı bir masalın derinliğinde kaybolurcasına akıp gidiyor." şeklindedir. Öğretmen liderler olmalarıla ilgili Ö4'ün görüşü; "Yönlendirmeyi, yönetmeyi, koordine etmeyi ve planlamayı çok seviyorum." şeklindedir. Mesleki özerklikle ilgili Ö4'ün görüşü; "Kendi tarzımı oluşturmaya çalıştım." şeklindedir. Öğrencileri takdir ederek cesaretlendirmeleri konusunda Ö8'in görüşü; "Sen bu görevin hakkını verirsin, üstesinden gelirsin diyorum." şeklindedir. Öğrenci merkezli öğretim yapmaları ile ilgili Ö4'ün görüşü; "Öğrencinin bulunduğu konuma göre, hazır duruşuna göre, var oluşuna göre." şeklindedir. Öğrencilerine empâti yaptırmaları ile ilgili Ö8'in görüşü; "Empâti kurmayı uygulatırım." şeklindedir. Farklı yöntem ve teknik kullanmaları konusunda Ö4'ün görüşü; "Mesleğimde hep böyle farklı metodolojiler geliştirmeye çalıştım. Farklı ölçme ve değerlendirme teknikleri uyguladım." şeklindedir. Güncelle bağlantı kurmalarıyla ilgili Ö8'in görüşü; "Hayatın içerisindeki her kareyi, çocuklara, öğrencilerime onları yaşatmayı, hissettirmeyi amaçladım ben." şeklindedir.

Yılın öğretmenlerinin mesleki tutum ve değerleri; fedakârlık yapmaları (f:7), öğretmenlik meslek sevgisine sahip olmaları (f.6), öğrenciye samimiyet göstermeleri (f.6), öğretmen ile öğrenci arasında karşııklı güven duygusunu tesis etmeleri (f.6), öğrencilerine okul dışında da zaman ayırmaları $(f .6)$, mesleki gelişimlerine önem vermeleri $(f .5)$, mezun ettikleri öğrencilerle iletişim kurmaları (f.5), velileriyle işbirliği yapmaları ( $f .4)$, öz değerlendirme yapabilmeleri $(f: 3)$, tüm öğrencileri kabul edebilmeleri ( $f .3)$, öğretmenlik mesleğini kutsal görmeleri ( $f .3)$, öğrencilerin gelişim ve öğrenmesini takip etmeleri $(f: 3)$, üsluba dikkat etmeleri $(f: 2)$ mesleği isteyerek seçmeleri ( $f .2)$, rol model olmaları (f:2), rehberlik yapmaları ( $f .2)$, değerler eğitimini önemsemeleri $(f .2)$, hoşgörülü olmaları (f.1), mesleki sorumluluk duymaları (f.1), şefkatli olmaları (f.1), çocuğun hayal dünyasına girebilmeleri ( $f .1)$ şeklindedir. 
Tablo 3. Yılın Öğretmenlerinin Mesleki Özellikleri

\begin{tabular}{|c|c|c|c|c|c|}
\hline Tema & Alt Tema & Kodlar & $f$ & Katılımcılar & Gösterge \\
\hline \multirow{31}{*}{ 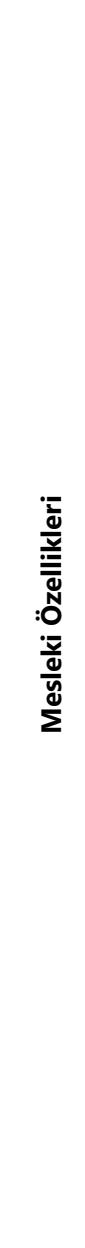 } & Mesleki Bilgi & Alan hâkimiyeti & 4 & Ö1, Ö2, Ö5, Ö7 & A.2.1. \\
\hline & & Öğrencinin hayatına dokunma & 8 & Ö1,Ö2,Ö3,Ö4,Ö5,Ö6,Ö7,Ö8 & B3.4. \\
\hline & & Dersi sevdirme & 6 & Ö1, Ö2, Ö4, Ö5, Ö7, Ö8 & B3.3. \\
\hline & & Liderlik & 5 & Ö1, Ö2, Ö4, Ö7, Ö8 & B3.12. \\
\hline & Mesleki Beceri & Mesleki özerklik & 5 & Ö1, Ö3, Ö4, Ö5, Ö7 & B1.3. \\
\hline & Mesleki Tutum & Öğrencileri takdir etme & 4 & Ö1, Ö2, Ö4, Ö8 & B4.4. \\
\hline & ve Değerler & Öğrenci merkezli öğretim & 4 & Ö4, Ö5, Ö7, Ö8 & B3.3 \\
\hline & & Öğrenciye empâti yaptırma & 3 & Ö4, Ö7, Ö8 & B3.1. \\
\hline & & Farklı yöntem ve teknik & 2 & Ö4, Ö7 & B1.3. \\
\hline & & Güncelle bağlantı kurma & 2 & Ö4, Ö8 & B3.4 \\
\hline & \multirow{21}{*}{$\begin{array}{c}\text { Mesleki Tutum } \\
\text { ve Değerler }\end{array}$} & Fedakârlık yapma & 7 & Ö1,Ö2,Ö3,Ö4,Ö5,Ö7,Ö8 & C2.1. \\
\hline & & Meslek sevgisi & 6 & Ö1, Ö2, Ö3, Ö4, Ö7, Ö8 & C4.1. \\
\hline & & Öğrenciye samimiyet gösterme & 6 & Ö1, Ö2, Ö3, Ö5, Ö6, Ö8 & C2.1. \\
\hline & & Karşılıklı güven duyma & 6 & Ö1, Ö2, Ö4, Ö5, Ö7, Ö8 & C2.2. \\
\hline & & Öğrenciye okul dışı zaman & 6 & Ö1, Ö3, Ö5, Ö6, Ö7, Ö8 & C2.3. \\
\hline & & Mesleki gelişime önem verme & 5 & Ö2, Ö3, Ö6, Ö7, Ö8 & C4.3. \\
\hline & & Mezun öğrencilerle iletişim & 5 & Ö3, Ö4, Ö5, Ö7, Ö8 & C2.1. \\
\hline & & Velilerle işbirliği yapma & 4 & Ö1, Ö5, Ö7, Ö8 & C3.5. \\
\hline & & Öz değerlendirme yapabilme & 3 & Ö1, Ö4, Ö5 & C4.2. \\
\hline & & Tüm öğrencileri kabul edebilme & 3 & Ö1, Ö5, Ö7 & C2.1. \\
\hline & & Mesleği kutsal görme & 3 & Ö2, Ö4, Ö6 & C4.6. \\
\hline & & Öğrenci gelişimini takip etme & 3 & Ö3, Ö5, Ö7 & C2.3. \\
\hline & & Üsluba dikkat etme & 2 & Ö2, Ö3 & C3.1. \\
\hline & & Mesleği isteyerek seçme & 2 & Ö2, Ö4 & C4.1. \\
\hline & & Rol model olma & 2 & Ö3, Ö5 & C2.4. \\
\hline & & Rehberlik yapma & 2 & Ö3, Ö8 & C2.3. \\
\hline & & Değerler eğitimini önemseme & 2 & Ö5, Ö8 & C1.3. \\
\hline & & Hoşgörülü olma & 1 & Ö1 & C3.3. \\
\hline & & Mesleki sorumluluk duyma & 1 & Ö3 & C4.6. \\
\hline & & Şefkatli olma & 1 & Ö8 & C2.1. \\
\hline & & Çocuğun hayal dünyasına girme & 1 & Ö8 & C2.3. \\
\hline
\end{tabular}

Not: Gösterge: Öğretmenlik mesleği genel yeterliklerinde belirtilen gösterge kod numaraları (MEB, 2017).

Mesleki tutum ve değerler alt temasında, mesleklerinde özveriyle çalışarak fedakârlık yapmaları ile ilgili Ö5'in görüşü; "Fedakârlık istiyor, eylem kısmı, en zor kısmı burası oluyor." şeklindeyken, Ö7'nin görüşü; "Benim öğretmenliğim mesai saatleriyle ya da gün ile sınırlı değil, yılın 365 günü sürekli olarak mesleğimle ilgili bir şeyler yapıyorum." şeklindedir. Meslek sevgisine sahip olmalarıyla ilgili Ö2'nin görüşü; "Ben bu mesleğe aşk ölçüsünde bağlı bir adamım." şeklinde iken, Ö7'nin görüşü; "Öğretmenliği bir meslek olarak değil, bir hayat sitili olarak görüyorum." şeklindedir. Öğrenciye samimiyet göstermeleri ile ilgili Ö2'nin görüşü; "Onlara sunduğum derslerde ve eğitim amaçlı konuşmalarımda bütün ifadelerime samimiyetimin rengini kattım." şeklindedir. Öğrencileri ile karşılıklı güven duygusunu tesis etmeleri ile ilgili Ö1'in görüşü; "Güvenmeleri, inanmaları yani ne desem maddi olarak da desem, manevi olarak da desem." şeklindedir. Öğrencilerine okul dışında da zaman ayırmaları ile ilgili Ö6'nın görüşü; "Öğrencilerimizle irtibatlarımız okul dışında da devam ediyor." şeklindedir. Mesleki gelişimlerine önem vermeleri ile ilgili Ö2'nin görüşü; "Okumayan araştırmayan bir öğretmen, tekrardan öteye gidemez, bu anlamda ögrretmenin de sürekli okuması, araştırması gerekir, ben kendimi mesleki olarak böyle tanımlıyorum." şeklindedir. Mezun ettikleri öğrencilerle iletişim kurmaları ile ilgili Ö5'in görüşü; "Benim mezun ettiğim evli öğrencilerim var, hala ararlar görüşürüz." şeklindedir. Veli işbirliği yapmaları ile ilgili Ö8'in görüşü; "Velilerimi de katarım, velisiz hiçbir zaman yol almam ben." şeklindedir. Öz değerlendirme yapabilmeleri ile ilgili Ö1'in görüşü; "Öğrencilere mektup yazdırtırım. Neyi doğru yaptım, neyi yanlış yaptım, bu noktada bana tavsiye edeceğiniz ne var?" şeklindedir. Tüm öğrencileri kabul edebilmeleriyle ilgili Ö1'in görüşü; "Hiçbir öğrenciye düşman değilimdir, asla kötülük beslemem, benim için hepsi değerlidir." şeklindedir. Öğretmenlik 
mesleğini kutsal görmeleri ile ilgili Ö2'nin görüşü; "Zira bu meslek peygamberlik mesleğidir, biz öğretmenler bu cennet bahçelerinin bahçıvanlarıyız, biz yürekleri kevser akan gül kokan yetiștiricileriyiz." şeklindedir. Öğrencilerin gelişim ve öğrenmesini takip etmeleri konusunda Ö7'nin görüşü; "Gelişimlerini, bir sonraki sınıfa ne durumdalar, nasıllar, bunları gözlemlerim mutlaka." şeklindedir. Üsluba dikkat etme ile ilgili Ö2'nin görüşü; "Kurduğunuz cümlelere uygun sözcük seçimi yaparsanız." şeklindeyken, Ö3'ün görüşü; "Al değnek dağlarda şarkı söyle diyen şaire kulak verip, elimde tebeşirle şarkılar söylemek istiyordum, sesimin sınırlarına uydum tabii." şeklindedir. Öğrencilere rol model olmaları ile ilgili Ö5'in görüşü; "Öğrenci benim hayatımda o doğruyu görmezse, doğruya inanamaz." şeklindedir. Rehberlik yapmaları ile ilgili Ö3'ün görüşü; "Yedi yirmi dört rehberlik yapıyorduk." şeklindedir. Değerler eğitimini önemsemeleri ile ilgili Ö8'in görüşü; "Sınıfa girdiğimde[öğrenci] ayak ayak üstüne atmış, ağzında sakız var, lakaytsa, başta onu düzeltmeye çalışırım." şeklindeyken, şefkatli olmaları ile ilgili Ö8'in görüşü; "Öğrencilerime başkasının çocuğu gözüyle değil, kendimden bir parçaymış gibi bakarak ilgiyle, şefkatle o şefkat çok önemlidir, yaklaşmaya çalışıyorum." şeklindedir.

\section{Yılın Öğretmenlerinin Yaptıkları Çalışmalar}

Yılın öğretmenlerinin çalışmaları, akademik, sosyal, kültürel ve sportif faaliyetler olarak temalara ayrılmıştır. Yılın öğretmenlerinin çalışmaları Tablo 4'te sunulmuştur.

Tablo 4. Yılın Öğretmenlerinin Çalışmaları

\begin{tabular}{clll}
\hline \multicolumn{1}{c}{ Tema } & Kodlar & $\boldsymbol{f}$ & Katılımcılar \\
\hline \multirow{4}{*}{ Akademik Faaliyet } & Ücretsiz kurslar & 4 & Ö1, Ö3, Ö5, Ö7 \\
& Eğitim-öğretim yarışmaları & 2 & Ö3, Ö7 \\
& Tübitak vb. projeler & 2 & Ö4, Ö7 \\
& Online soru çözümleri & 1 & Ö4 \\
& Bilimsel makale yazma & 1 & Ö7 \\
\hline & Sosyal sorumluluk projeleri & 6 & Ö1, Ö3, Ö4, Ö5, Ö7, Ö8 \\
& STK işbirliği & 3 & Ö5, Ö6, Ö7 \\
& Veli ziyaretleri & 3 & Ö1, Ö7, Ö8 \\
& Geziler & 3 & Ö3, Ö7, Ö8 \\
& Yabancı uyruklu öğrenci projeleri & 1 & Ö6 \\
& Toplum hizmeti & 1 & Ö7 \\
\hline \multirow{5}{*}{ Kosyal Faaliyet } & Edebiyat alanında yarışmalar & 3 & Ö1, Ö2, Ö3 \\
& Kitap okuma kampanyaları & 3 & Ö1, Ö3, Ö5 \\
& Yazar-öğrenci buluşmaları & 3 & Ö1, Ö3, Ö8 \\
& Kitap ve dergi yazarlığı & 3 & Ö2, Ö3, Ö7 \\
& Konferans, sempozyum, söyleşi & 1 & Ö3 \\
& Resim sergisi açma & 1 & Ö3 \\
& Şehit ailelerini ziyaret & 1 & Ö5 \\
& Tiyatro faaliyetleri & 1 & Ö8 \\
\hline \multirow{2}{*}{ Spartif Foaliyet } & 1 & Ö4 \\
\hline
\end{tabular}

Yılın öğretmenlerinin akademik faaliyetleri; ücretsiz kurslar $(f: 4)$ ve eğitim-öğretim yarışmaları düzenleyerek $(f: 2)$ Tübitak vb. projelere katılmaları $(f: 2)$, online soru çözümleri yapmaları $(f: 1)$ ve bilimsel makale yazmaları $(f: 1)$ şeklindedir.

Akademik faaliyetler temasında, ücretsiz kurslar düzenlemeleri ile ilgili Ö1'in görüşü; "Hafta sonu hiçbir maddi şey düşünmeksizin, ücretsiz kurs başlatmıştık." şeklindedir. Eğitim öğretim yarışmaları ile ilgili Ö3; "Bilgi yarısması, üç katılım, bir birincilik, bir ikincilik derecesi, şiir okuma yarışmaları, okul içi ve il geneli." şeklinde görüş belirtirken. Ö7'nin görüşü; "2012'de vitamin ögretmenin "Ögretmenler üretiyor" diye bir yarışması vardı video ders anlatım yarışması, ona katıldım, orda da derece yaptık, öngep çalışmasına davet edildik." şeklindedir. Tübitak vb. projelere başvuru yapmaları ile ilgili Ö4'ün görüşü; "O lisenin tarihinde ilk defa başvurulan bir Tübitak projesi finale kaldı, o proje ben ve öğrencilerim tarafından yürütülmüştü. Ardından, olumsuz atasözü ve deyimlerin kadınların sosyal psikolojik ve iş hayatlarındaki etkisini araştıran bir projede başarılı olduk." şeklindedir. Ö7'nin görüşü; "Biz köy muhtarıyla beraber "Temiz köyüm temiz beldem" diye Çevre Bakanlığının bir yarışması vardı, hem aileleri bilinçlendirerek, 
bilgilendirecek şekilde, hem çocukları bilinçlendirerek, bilgilendirecek şekilde çalışma yaptık ve ikinci olduk Türkiye'de, ilk çalışmamız buydu, Türkiye'nin en temiz 2. Köyü olarak seçildi. Ikincisi ... Orman Bölge Müdürlügü ile görüştüm ben, pil topladık. Onlar her pil için bize bir fidan verdiler. Fidanlar köyün farklı yerlerine dikildi." şeklindedir. Öğrencilere online soru çözümü, yapmaları ile ilgili Ö4'ün görüşü; "Biz meslek lisesinde çalışırken, Eba altyapısını kullanarak online soru çözümleri vs. bir çalışmamı olmuştu." şeklindedir.

Yılın öğretmenlerinin sosyal faaliyetleri; sosyal sorumluluk projeleri $(f: 6)$ ve sivil toplum kuruluşları (STK) ile işbirliği yapmaları $(f: 3)$, veli ziyaretleri yaparak $(f: 3)$ geziler düzenlemeleri $(f: 3)$ şeklindedir.

Sosyal faaliyetler temasında, sosyal sorumluluk projeleri yapmaları ile ilgili Ö3'ün görüşü; "Okul içerisinde yardım amaçlı ... organizasyonları." STK işbirliği ile ilgili Ö6'nın görüşü; "Milli eğitimin içerisinde, STK'lar içerisinde katıldı̆ımız birçok proje var." şeklindedir. Veli ziyaretleri ile ilgili Ö8 görüşünü; "Öğrenciyi anlamanın en iyi yolunun veli ziyaretleri olduğuna inanıyorum ve yıllardır bunu yapıyorum." şeklinde belirtmiştir. Geziler düzenlemeleri ile ilgili Ö3'ün görüşü; "Öğrencileri ve öğretmenleri içine alan Çanakkale-Bursa, Istanbul, Kayseri-Kapadokya-Konya gezilerinin organizasyonu." şeklindedir.

Yııın öğretmenlerinin kültürel faaliyetleri; edebiyat alanında yarışmalara katılım göstermeleri (f:3), kitap okuma kampanyaları düzenlemeleri (f:3), yazar-öğrenci buluşmaları (f:3), kitap ve dergi yazarlığı yaparak bilgi ve değer üretiminde bulunmaları $(f: 3)$, şehit ailelerini ziyaret $(f .1)$ şeklindedir.

Kültürel faaliyetler temasında, edebiyat alanında yarışmalar ile ilgili Ö1'in görüşü; "Şiir ve kompozisyon yarışmalarında Türkiye derecemiz, bir tane uluslararası yarışma vardı, onda dünya birinciliği vardı." şeklindedir. Kitap okuma kampanyaları ile ilgili Ö1 görüşünü; "Her ay bir kitap okutmak, en önemli şeylerden bir tanesi buydu." şeklinde belirtirken, yazar öğrenci buluşmaları ile ilgili Ö8 görüşünü; "Okur, yazar, şair, öğrenci buluşması, birçok yazar ve şairle öğrencileri buluşturduk." şeklinde belirtmiştir. Kitap ve dergi yazarlığı ile ilgili ise Ö2'nin görüşü; "Yayınlamış olduğum dokuz eserin içerisinde roman, hikâye, deneme, şiir, mektuplar, biyografik roman türleri var." şeklindedir. Şehit aile ziyaretleri ile ilgili Ö5'in görüşü; "Biz şehit ailelerini, eşlerini ve çocuklarını bire bir [öğrencilerle] görüştürdük. Çünkü çocuğun kalbine değinmiş oldum. Yaşattım o duyguyu, hissetti yani temel öğretmenlik hayatım boyunca temel prensibim bilgiyi ögrrenmekten ziyade bilgiyi yaşamak önemli, hani ona dokunmalı o bilgi." şeklindedir.

Yılın öğretmenlerinin sportif faaliyetleri; spor yarışmalarına katılım $(f: 1)$ şeklindedir. Bununla ilgili Ö4'ün görüşü; "Yaptığım çalışmalardan badminton antrenörlüğüm içerisinde iki, üç defa il şampiyonluğum oldu, aynı okulda." şeklindedir.

\section{Yılın Öğretmenlerini Motive Eden Faktörler}

Yılın öğretmenlerini motive eden faktörler, içsel ve dışsal motivasyon unsurları olarak bulut gösteriminde iki alt temaya ayrılmıştır. Yılın öğretmenlerinin motive unsurları Şekil 2'de sunulmuştur.
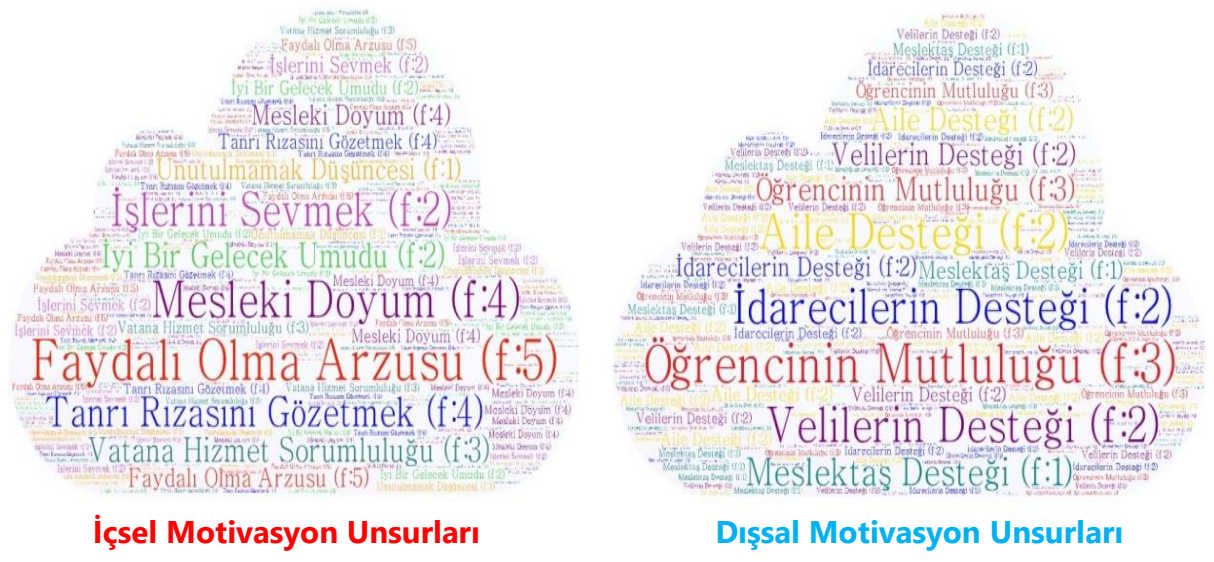

Şekil 2. Yılın öğretmenlerinin motivasyon unsurları bulut gösterimi 
Yılın öğretmenlerinin içsel motivasyon unsurları; faydalı olma arzusu (Ö2, Ö5, Ö6, Ö7, Ö8), Tanrı rızasını gözetmek (Ö2, Ö3, Ö5, Ö6), mesleki doyum (Ö1, Ö3, Ö4, Ö8), vatana hizmet sorumluluğu (Ö2, Ö5, Ö6), iyi bir gelecek umudu taşımak (Ö5, Ö8), işlerini sevmek (Ö5, Ö8), unutulmamak düşüncesi (Ö2) şeklindedir.

İçsel motivasyon unsurları alt temasında, faydalı olma arzusuyla ile ilgili Ö2'nin görüşü; "Halka hizmet Hakk'a hizmettir anlayışıla öğrencilerime, şehrimin insanlarına, ülkemin insanlarına güzellikler adına bir şeyler sunabilme anlayışı beni motive eden en önemli bir etkendir." şeklindeyken, Tanrı rızasını elde etmeyle ilgili Ö5'in görüşü ise; "Herkesin değişik motivasyon unsurları var, bunlardan birincisi inancım en önce, çünkü dünyaya geliş amacımızı gerçekleştirme, Allah'a iyi bir kul olma." şeklindedir. Mesleki doyumla ilgili Ö4 görüşünü; "Yani mesleki doygunluk, tatmin, yaptığını işi iyi yapmak, kazancınıı helal bir şekilde elde etmenin verdiği huzurla başınızı yastığa koymak, beni en çok motive eden şey." şeklinde belirtirken, vatana hizmet etme ile ilgili Ö5 görüşünü; "Üzerinde yaşadığım topraklara karşı borcum var, vatan toprağına borcum var." şeklinde belirtmiştir. İyi bir gelecek umudu ile ilgili Ö8 görüşünü; "Bir amacım var, yani iyi bir gelecek." şeklinde belirtirken, işlerini severek yapmalarılla ilgili Ö5 görüşünü; "Işi ne kadar ciddiyetle yapıyorsanı, ne kadar severek yapıyorsanız, ne kadar sevme, yaşatma işini yapıyorsanız o kadar başarılı olursunuz." şeklinde belirtmiştir. Unutulmamak düşüncesiyle ilgili görüşünü Ö2; "Arkamdan dua edenim çok olsun diye, bu şehrin semalarında hoş bir seda olarak kalayım diye hep düşündüm, adımlarımı hep ona göre attım. Unutulmamak, bu da motivasyonumun bir başka yanıdır." şeklinde belirtmiştir.

Yılın öğretmenlerinin dışsal motivasyon unsurları; öğrencinin mutluluğu (Ö1, Ö7, Ö8), velilerin desteği (Ö1, Ö7), idarecilerin desteği (Ö1, Ö3), kendi ailelerinin desteği (Ö1, Ö3), meslektaş desteği (Ö3) şeklindedir.

Dışsal motivasyon unsurları alt temasında, öğrencinin mutluluğu ile ilgili Ö7'nin görüşü; "Çocukları mutlu etmek benim temel motivasyon kaynağım, kesinlikle temel sebep o, zaten ögretmenlikte tutunabilmenin de temel yolu o, yoksa devlet memuru oluyorsunuz ögrretmen olmuyorsunuz." şeklindedir. Velilerin desteği ile ilgili Ö7'nin görüşü; "Ailelerin tavırları, tutumları, bize destekleri de bizim için ayrıca motivasyon kaynağı." şeklindedir. İdarecilerin desteği ile ilgili Ö3 görüşünü; "Birlikte çalıştığım idareci arkadaşların bize güveni." şeklinde belirtirken, kendi ailelerinin desteği ile ilgili görüşünü Ö1; "Ailem bu noktada bana destek veriyor." şeklinde, meslektaş desteği ile ilgili ise görüşünü Ö3; "Arkadaşlarımın iş yapma arzusu." şeklinde belirtmiştir.

\section{Yılın Öğretmeni OImanın Mesleğe ve Sosyal Hayata Yansımaları}

Yılın öğretmeni olmanın yansımaları, mesleğe ve sosyal hayata yansımalar şeklinde alt temalara ayrıımıştır. Yılın öğretmeni olmanın yansımaları Şekil 3'te sunulmuştur.

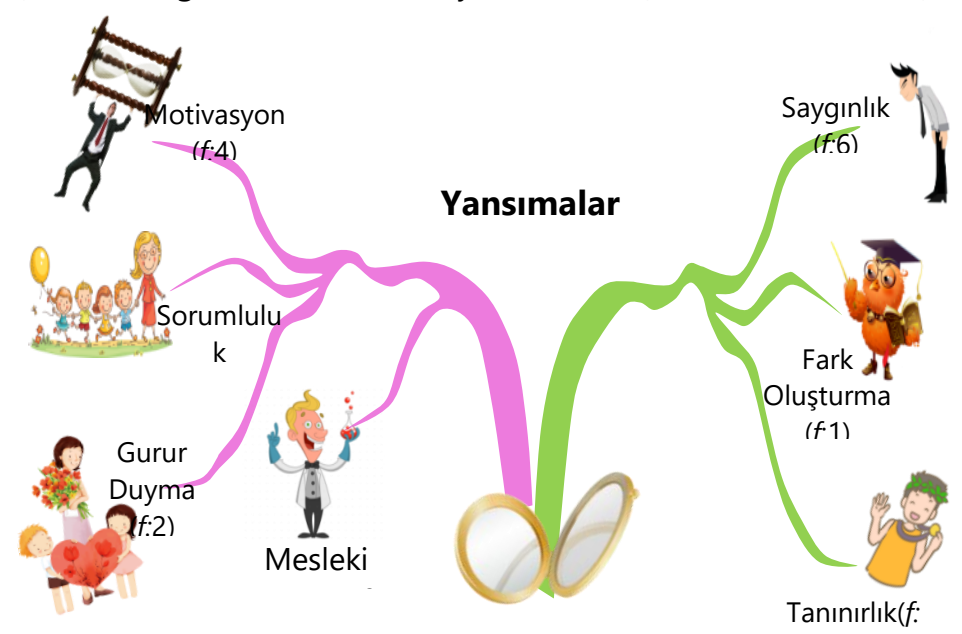

Şekil 3. Yılın öğretmeni olmanın mesleğe ve sosyal hayata yansımaları. 
Yılın öğretmeni olmanın yansımaları, mesleğe yansımalar; motivasyonun artması (Ö1, Ö4, Ö6, Ö7), mesleki sorumluluk (Ö4, Ö6), mesleğiyle daha çok gurur duyma (Ö1, Ö4), mesleki heyecan (Ö7) şeklinde, sosyal hayata yansımalar; saygınlığın artması (Ö1, Ö2, Ö3, Ö4, Ö7, Ö8), tanınırlık etkisi (Ö2, Ö3, Ö4, Ö5, Ö6, Ö8) ve fark oluşturma (Ö4) şeklinde iki kategoriye ayrılmıştır.

Mesleğe yansımalarda motivasyonun artması ile ilgili Ö4; "Bu size çok güç katıyor yani çalışmalarınızda daha da güçlenmenizi sağlıyor." biçiminde görüşünü belirtmiştir. Mesleki sorumluluk duygularının güçlenmesiyle ilgili Ö4'ün görüşü; "Bunun sorumluluğunu taşıyorsunuz, daha dikkatli oluyorsunuz." şeklindedir. Mesleğiyle daha çok gurur duymaları ile ilgili Ö1; "Yaptığım mesleği gururla yapmam ve daha çok sarılmamı sağladı." biçiminde görüşünü belirtirken, mesleki heyecan ile ilgili görüşünü Ö7; "Ben bunu duyduğum gün, öğrendiğim gün, sanki yeniden göreve başlamış gibi hissettim." biçiminde ifade etmiştir.

Sosyal hayata yansımalarda saygınlığın artması ile ilgili Ö1'in görüşü; "Gerçekten saygı duyuyorlar, evet, hocamı mesleğinde çok iyi, o noktada saygı duyuyoruz, bu türden şeyler gerçekten hayatımızı çok olumlu etkiliyor." biçimindeyken, Ö2 görüşünü; "Saygınlığını çoğalıyor, yılın ögrretmeni seçilmiş olmak. Şöyle düşünün derse girip çıkıyorsunuz öğrencilerin size bir bakışı var, sonra yılın öğretmeni olarak aynı sınıfa tekrar girdiğinizde önceki bakışların yerini hayranlık uyandıran bakışlar alıyor." biçiminde belirtmiştir. Tanınırıkla ilgili Ö5'in görüşü; "Bir köy ögrretmeninin benden belki binlerce kat daha fazla çalıştığına inanırım. Ama gözden ıraktır değerlendirilemiyordur her an." şeklindeyken, Ö2; "Her şeyden evvel çok tanınan, çok bilinen, adından sıkça söz edilen, hatırlanan birileri oluyorsunuz." biçiminde, fark oluşturma ile ilgili ise Ö4; "Yılın öğretmeni olarak görüldüğünüz noktada bu, fark yaratmamızı sağlıyor." şeklinde görüş belirtmiştir.

\section{Yılın Öğretmenlerinin Özelliklerine ilişkin Bulgulardan Ortaya Çıkan Model}

Yılın öğretmenlerine bütüncül bir bakış açısı sunulması amacıyla bulgulardan ortaya çıkan bir modelleme yapılmıştır. Yılın öğretmenlerinin özelliklerine ilişkin bulgulardan çıkan model Şekil 4'te sunulmuştur.

\begin{tabular}{|c|c|c|}
\hline Kişisel Özellikleri & & Mesleki Özellikleri \\
\hline $\begin{array}{l}\text { - Toplumsal sorunlara duyarlı olma } \\
\text { - Vatan evlatları yetiştirme arzusu } \\
\text { - Maneviyata önem verme } \\
\text { - İşbirliği } \\
\text { - Empati } \\
\text { - Güçlü iletişim } \\
\text { - Samimiyete önem verme } \\
\text { - Çocukları sevme } \\
\text { - Hoşgörülü olma } \\
\text { - İhtiyaca duyarlı olma } \\
\text { - Kendini tanıma } \\
\text { - Verilen görevi tamamlama }\end{array}$ & $\begin{array}{c}\text { Yılın } \\
\text { Öğretmeni } \\
\text { Modeli }\end{array}$ & $\begin{array}{l}\text { - Öğrencinin hayatına dokunma } \\
\text { - Fedakârlık } \\
\text { - Meslek sevgisi } \\
\text { - Öğrenciye samimiyet gösterme } \\
\text { - Karşılıklı güven duyma } \\
\text { - Öğrenciye okul dışı zaman ayırma } \\
\text { - Dersi sevdirme } \\
\text { - Liderlik } \\
\text { - Mesleki özerklik } \\
\text { - Mesleki gelişimine önem verme } \\
\text { - Mezun öğrencilerle iletişim } \\
\text { - Öğrencileri takdir etme } \\
\text { - Öğrenci merkezli öğretim } \\
\text { - Veli işbirliği } \\
\text { - Alanlarına hâkim olma }\end{array}$ \\
\hline Motivasyon Unsurları & & Yaptıkları Çalışmalar \\
\hline $\begin{array}{l}\text { - Faydalı olma arzusu } \\
\text { - Tanrı rızasını gözetmek } \\
\text { - Mesleki doyum } \\
\text { - Vatana hizmet sorumluluğu } \\
\text { - Öğrencinin mutluluğu } \\
\text { - İyi bir gelecek umudu } \\
\text { - İşlerini sevmek } \\
\text { - Velilerin desteği } \\
\text { - İdarecilerin desteği } \\
\text { - Kendi ailelerinin desteği }\end{array}$ & & $\begin{array}{l}\text { - Sosyal sorumluluk projeleri } \\
\text { - Ücretsiz kurslar } \\
\text { - STK işbirliği } \\
\text { - Veli ziyaretleri } \\
\text { - Edebiyat alanında yarışmalar } \\
\text { - Kitap okuma kampanyaları } \\
\text { - Yazar-öğrenci buluşmaları } \\
\text { - Kitap ve dergi yazarlığı } \\
\text { - Geziler } \\
\text { - Eğitim-öğretim yarışmaları }\end{array}$ \\
\hline
\end{tabular}

Şekil 4. Yılın öğretmenlerinin ortak özellikleri 


\section{SONUÇ, TARTIŞMA VE ÖNERILER}

Araştırmada, yılın öğretmenlerinin; yaptıkları çalışmaları, motivasyon unsurlarını, kişisel ve mesleki özelliklerini, yılın öğretmeni olmalarının mesleğe ve sosyal hayata yansımalarını belirlemek amaçlanmıştır.

Araştırmada, yılın öğretmenlerinin mesleki özerkliğe sahip olduğu sonucuna ulaşılmıştır. Bu sonucun çıkmasında öğretmenlerin genel anlamda özerkliği kullanmaya istekliliğinin (Çolak ve Altınkurt, 2017) yılın öğretmenlerinde de görülmesinin etkisi olabilir. Türkiye'de öğretmen özerkliğinin oldukça sınırlandırımasına (Bümen, 2019) rağmen yılın öğretmenlerinin mesleki özerkliğe yatkın olmaları şeklinde sonucun çıkması, yılın öğretmenlerinin özyeterlik algılarının yüksek olmasından, profesyonel özellikler sergileyerek yaptıkları çalışmaların olumlu sonuçlanmasından kaynaklanmış olabilir. Araştırmada yılın öğretmenlerinin kendini tanıma, kendi duygularını yönetebilme, kendini harekete geçirebilme, başkalarının duygularını anlama, ilişkileri yürütebilme, sosyal becerilere sahip olma gibi özellikler göstermesi, bu öğretmenlerin duygusal zekâlarını etkin bir şekilde kullandıkları şeklinde yorumlanabilir. Bahsedilen bu özellikler, duygusal zekanın bileşenleri olan özbilinç, özdenetim, motivasyon, empati, sosyal beceri kavramları (Goleman, 2011) ile örtüşmektedir. Yılın öğretmenlerinin duygusal zekâlarını kullanmaları, öğretmenler arasında güven ortamının oluşmasına, işbirlikli okul ikliminin yaşanmasına da katkı sağlamış olabilir (İsmayılov, 2019).

Araştırmada, yılın öğretmenlerinin mesleki özellikleri içerisinde öz değerlendirme yaptıkları sonucuna ulaşılmıştır. Yılın öğretmenlerinin öz değerlendirme yapmaları aynı zamanda iyi öğretmen olma özellikleri de (Kızıltepe, 2002) sergiledikleri şeklinde yorumlanabilir.

Yılın öğretmenlerinin velilerle işbirliği yapmaları, mesleki özellikleri arasında yer almaktadır. Eğitim sistemlerinde önemli bir paydaş olan velilerin, öğretmenlerin yapacağı birçok faaliyette başarılı olabilmeleri adına destekleyici konumda bulunabilmeleri gerekmektedir. Bunu sağlamanın yolu, işbirliğine dayalı bir iletişimi kullanmaktan geçmektedir. Bu açıdan yılın öğretmenleri, yaptıkları faaliyetlerde başarılı olabilmeleri için veli desteğine ihtiyaç duymuş ve bu doğrultuda velilerle işbirliğine girmiş olabilirler. Ayrıca velilerle geçekleşen işbirliği, öğrencilere birçok yönden olumlu katkı sağlamaktadır (Aslanargun, 2007). Bu katkılar; öğrencilerin okula bağlılıklarını artırma, ders başarısını artırma, sorumluluklarını yerine getirme, sınıf aktivitelerine katılma, ödevlerini tamamlama ve olumlu davranışlar geliştirme şeklinde sıralanabilir.

Araştırmada, yılın öğretmenlerinin öğrencilerin hayatına dokunarak olumlu izler bıraktıkları sonucuna ulaşımıştır. Bu sonuç, Koşar'ın (2019) çalışmasında ulaştığı, öğretmen olmanın öncelikle hayata dokunma olduğu ile Çetin ve Ünsal'ın (2020) çalışmalarında ulaştığı, fark oluşturan öğretmenin, öğrencilerin hayatına dokunabilme özelliğine sahip olmaları şeklindeki sonuçları desteklemektedir. Araştırmada, yılın öğretmenlerinin kişisel özelliklerinde bulunan çocukları sevme ile mesleki özelliklerinde bulunan meslek sevgisine sahip olmaları, kişisel ve mesleki özelliklerinin birbiriyle ilişkili olduğu şeklinde de yorumlanabilir. Bu doğrultuda yılın öğretmenlerinin çocukları sevmeleri, mesleklerini severek yapmalarına neden olmuş olabilir.

Araştırmada yılın öğretmenlerinin mesleki gelişimlerine de önem verdikleri sonucuna ulaşıımışıır. Türkiye'de mesleki gelişimde, engeller bulunmasına (Can, 2019; Yirci, 2017), düzenlenen faaliyetlerin intiyacı karşılamaktan uzak (Elçiçek ve Yaşar, 2016), sayısının ve niteliğinin yetersiz olmasına (Çetin ve Sadık, 2020), mevcut uygulanan şekliyle işlevsel olmamasına (Kahyaoğlu ve Karataş, 2019) karşın yılın öğretmenlerinin mesleki gelişimlerine önem vererek kendilerini geliştirmeleri, araştırmanın dikkat çekici bir sonucudur. Bu sonucun çıkması, yılın öğretmenlerinin mesleki gelişimin öneminin farkında olmalarından ve mesleği sevmelerinden (Eroğlu ve Özbek, 2020) kaynaklanmış olabilir.

Yılın öğretmenleri öğrencinin hayatına dokunma, fedakârlık, çocukları sevme, mesleği sevme, öğrenciye samimiyet gösterme, karşılıklı güven duyma, tüm öğrencileri kabul edebilme, öğrencilere okul dışı zaman ayırma gibi kişisel ve mesleki özellikler göstermektedir. Öğretmenlerin göstermiş olduğu bu özellikler, mesleki adanmışlık ile de yakından ilişkilidir (Turhan, Demirli ve Nazik, 2012). 
Yılın öğretmenlerinin liderlik özellikleri sergiledikleri, araştırmanın sonuçları arasında yer almaktadır. Liderlik, etkili öğretmen özellikleri arasında yer almaktadır (Çelikten, Şanal ve Yeni, 2005; Şişman, 2011). Bu açıdan yılın öğretmenlerinin liderlik özelliklerine sahip olmaları, etkili öğretmenlik özelliklerine de sahip oldukları şeklinde yorumlanabilir.

Araştırmada, yılın öğretmenlerinin kişisel özellikleri arasında bulunan güçlü bir iletişime sahip olma, empati yapma ve samimiyete önem verme özelliklerine sahip olduğu sonucuna ulaşılmıştır. Araştırmanın bu sonucunu, Başaran ve Baysal'ın (2016) ideal öğretmenler üzerine yapmış oldukları çalışmada ulaştıkları sonuç desteklemektedir.

Araştırmada, yılın öğretmenlerinin akademik, sosyal, kültürel, sportif birçok alanda ekstra çalışmalar yaptıkları sonucuna ulaşılmıştır. Yaptıkları bu çalışmaların okul yönetimi tarafından fark edilmesi, yııın öğretmeni seçilme sürecinin ilk adımları olarak yorumlanabilir. Yapılan faaliyetlerin somut olarak görülmesi ve çıtılarının hemen ölçülmesi, yılın öğretmenlerinin seçilmesinde bir avantaj sağlamış olabilir.

Araştırmada, yılın öğretmenlerinin Tübitak, Ulusal Ajans veya Avrupa Birliği gibi çeşitli kurumlar tarafından ilan edilen destek projelerini takip ettikleri ve bu projelere başvuru yaptıkları sonucuna ulaşılmıştır. Tatı'ya (2016) göre tüm öğretmenlerin eğitim alanında ilan edilen proje çağrılarına başvuru yapma imkânları bulunduğu halde, bu konuda yapılan başvurular oldukça yetersiz seviyededir. Yılın öğretmenlerinin eğitim alanında projelere başvuru yapmaları, bu yetersizliği giderme adına olumlu katkılar sağladıkları şeklinde yorumlanabilir.

Araştırmada, yılın öğretmenlerinin başarılı çalışmalarında, içsel motivasyon unsurlarının dışsal motivasyon unsurlarından daha güçlü ve daha etkili olduğu sonucuna ulaşılmıştır. Alan yazında bu sonucu destekleyen araştırma sonuçları (Ekinci, 2017; Ertürk, 2016) bulunmakla birlikte bu sonucu desteklemeyen araştırma sonuçları da bulunmaktadır (Arslantaş, Tösten ve Beştaş-Marakçı, 2018).

Yılın öğretmenleri, motivasyon kaynağı olarak iyi bir gelecek umuduna sahiptirler. Eğitimin, toplumların ve bireylerin yaşamlarını değiştirme gücüne sahip olduğu kabul edilmektedir. Diğer bir ifade ile eğitim, toplumları ve bireyleri değişim ve dönüşüme uğratarak onların daha iyiye doğru bir yol bulmasını amaçlar. Bu amaç sayesinde bireyler, yarınlarının daha iyi olmasında eğitimin önemli ve olumlu katkılar sağlayacağını düşünürler. Bu düşüncenin etkileri, yılın öğretmenlerinin iyi bir gelecek umuduna sahip olmalarında kendisini hissettirmiş olabilir. Yılın öğretmenlerinin iyi bir gelecek umuduna sahip olmaları şeklinde araştırmada elde edilen bu sonucu, Başaran ve Baysal'ın (2016) çalışmalarında, ideal öğretmenin kişisel özelikleri arasında gelecek umudu olma şeklinde ulaştıkları sonuç desteklemektedir.

Araştırmada, yılın öğretmeni olmanın, öğretmenlerin saygınlığını artırdığı sonucuna ulaşılmıştır. Öğretmenlerin toplumdaki saygınlığının giderek düştüğü (Can, 2019; Demir ve Arı, 2013; TEDMEM, 2014; Yıldız ve Ünlü, 2013), öğretmenler tarafından mesleklerinin hak ettiği saygınlığı yeterince göremediği (Karaman, Acar, Kılıç, Buluş ve Erdoğan, 2013) şeklindeki araştırma sonuçları, bu araştırmanın sonucuyla farklılaşmaktadır. Bu farklılaşma, kendi içerisinde bir tutarlıı̆ı da barındırmaktadır. Öğretmenliğin saygınlığını belirleyen faktörler arasında, öğretmenlerin yeterliği ve niteliği sayılmaktadır (Bozbayındır, 2019; Hargreaves, 2009; Hoyle, 2001; Ulutaş, 2017). Başka bir ifade ile öğretmenlerin mesleklerinde yeterli ve nitelikli olmaları, öğretmenlik mesleğinin saygınlığına olumlu yansımalar göstermektedir. Yılın öğretmenleri mesleki özellikleri ve yaptıkları çalışmalar doğrultusunda, öğretmen niteliği ve yeterliği açısından başarılı bulunarak yılın öğretmeni seçilmişlerdir. Doğal olarak yılın öğretmeni olmaları, öğretmenlerin saygınlığını artırmaya katkı sağlamakta, mesleğin saygınlığını artırma da öğretmen niteliğinin ve yeterliğinin önemini tekrar ortaya koyması açısından çarpıcı bir sonuç olmaktadır. Buna göre yılın öğretmenlerinin "öğretmenliğin meslekleşmesine" (Toprakçı, 2009) katkıda bulunduğu da söylenebilir.

Araştırmada, yılın öğretmeni olmanın saygınlığı artırdığı kadar tanınırlığa da olumlu yansımaları olduğu sonucuna ulaşılmıştır. Yılın öğretmeni seçilme sürecinin, okul idaresinden başlayarak ilçe ve il Milli Eğitim Müdürlükleri yönetimindeki karar vericilere doğru resmi 
yazışmalar içermesi, ayrıca informel ilişkiler ve iletişim ağının etkisi, yerel ve sosyal medyadaki haberler, yılın öğretmenlerinin tanınırlıklarının artmasını etkilemiş olabilir.

Araştırmanın dikkat çeken sonuçlarından bir diğeri, yılın öğretmenlerinin edebiyat alanında yarışmalara katılmaları, kitap, dergi yazarlığı ve tiyatro çalışmaları yapmalarıdır. Bu sonucun çıkması, yılın öğretmenleri içerisinde Edebiyat ve Türkçe branş öğretmenlerinin çoğunlukta olmasından kaynaklanmış olabilir.

Bu çalışmadan yılın öğretmenlerinin; kişisel ve mesleki özelliklerinin ideal, etkili, profesyonel ve fark oluşturan öğretmen özellikleri ile benzer olduğu, yaptıkları başarıı çalışmalarının ardında değerlerinden aldıkları güçlü içsel motivasyon unsurlarının etkisinin olduğu, böylece meslektaşları arasında fark oluşturdukları, mesleğin saygınlığının artmasında olumlu katkılarının olduğu, mesleki adanmışlık duygusuna ve belirli bir mesleki deneyime sahip olduğu şeklinde bir sonuç çıkarılabilir.

\section{Öneriler}

- Yılın öğretmeni belirleme sürecinde, MEB taşra teşkilatındaki karar vericiler tarafından, ildeki tüm öğretmenleri kapsayıcı şekilde öğretmenler teşvik edilerek, daha fazla öğretmenin değerlendirme sürecine dâhil edilebileceği bir yaklaşım sergilenebilir. Bu şekilde yılın öğretmenlerinin aynı veya benzer branşlardan seçilmeleri de önlenmiş olabilir.

- Yılın öğretmenleri ile ideal öğretmen, fark oluşturan öğretmen, öğretmen liderler gibi diğer öğretmen kavramsallaştırmaları ile benzerlik ve farklılıkları konu edinen çalışmalar yapılabileceği gibi, yılın öğretmenlerinin karşılaştıkları zorlukları, bu zorlukları aşma stratejileri, çalışma sistematikleri ve mesleğin imajına etkilerini konu edinen çalışmalar da yapılabilir.

- Bu çalışma Anadolu'nun bir ilinde, farklı yıllarda seçilen yılın öğretmenleri ile yürütülmüştür. Bulgular, bu bağlamda katılımcılardan toplanan verilerle sınırlıdır. Benzer çalışmalar farklı araştırma modeli ve veri toplama araçları kullanılarak yapılabilir.

\section{KAYNAKLAR}

Akcan, E., \& Polat, S. (2016). Eğitim konulu Türk filmlerinde öğretmen imajı: Öğretmen imajına tarihi bakış. Kuram ve Uygulamada Eğitim Yönetimi, 22(3), 293-320. doi: 10.14527/kuey.2016.012

Akçadağ, T. (2017). Köyde bir öğretim lideri: Dilek Livaneli. Kalem Eğitim ve Insan Bilimleri Dergisi, 7(2), 263-292. doi: $10.23863 /$ kalem.2018.87

Aldan-Karademir, Ç., \& Akgül, A. (2019). Öğretmenlerin "Etkili sosyal bilgiler öğretmeni" algısı: Nitel bir araştırma. Celal Bayar Üniversitesi Sosyal Bilimler Dergisi, 17(3), 186-207. doi: 10.18026/cbayarsos.532411

Arslantaş, H. İ.,Tösten, R., \& Beştaş-Marakçı, D. (2018). Lise öğretmenlerinde mesleki motivasyon unsurları: Karma yöntemli bir çalışma. Mersin Üniversitesi Eğitim Fakültesi Dergisi, 14(3), 880-895. doi: 10.17860/mersinefd.485161

Aslanargun, E. (2007). Okul - aile birliği ve öğrenci başarısı üzerine bir tarama çalışma. Manas Üniversitesi Sosyal Bilimler Dergisi, 18, 119-135.

Aypay, A. (2011). Illk ve ortaöğretim öğretmenlerinin davranış alışkanlıkları ve iyi öğretmen özelliklerine ilişkin algıları. Ilköğretim Online, 10(2), 620-645.

Balyer, A. (2016). Öğretmen liderler: Öğretmen algıları üzerine nitel bir araştırma. ElementaryEducation Online, 15(2), 391-407. doi: http://dx.doi.org/10.17051/io.2016.81764

Başaran, A. R., \& Baysal, S. (2016). Öğretmen adaylarının ideal bir öğretmen hakkındaki görüşleri. Ö. Demirel ve S. Dinçer (Ed.), Eğitim Bilimlerinde Yenilikler ve Nitelik Arayışı içinde (s.29-44). Ankara: Pegem Akademi. doi: http://dx.doi.org/10.14527/9786053183563.003

Berg, L. B., \& Lune, H. (2019). Sosyal bilimlerde nitel araştırma yöntemleri. (4. Baskı, Çev. H. Aydın). Ankara: Eğitim Yayınevi.

Bozak, A., Özdemir, T., \& Seraslan, D. (2016). Mesleğe yeni başlayan öğretmenlerin eğitim fakültelerinde almış oldukları öğretmenlik eğitimine ilişkin görüşleri. Mustafa Kemal Üniversitesi Sosyal Bilimler Enstitüsü Dergisi, 13(36), 100-113.

Bozbayındır, F. (2019). Öğretmenlik mesleğinin statüsünü etkileyen unsurların öğretmen görüşleri temelinde incelenmesi. Elektronik Sosyal Bilimler Dergisi, 18(72), 2076-2104. doi: 10.17755/esosder.583274 
Bright, N. H. (2011). Fivehabits of highly effective teachers. School Administrator, 9(68), 33-35. Erişim adresi: https://www.aasa.org/SchoolAdministratorArticle.aspx?id=20462

Bümen, N. T. (2019). Türkiye'de merkeziyetçiliğe karşı özerklik kıskacında eğitim programları: Sorunlar ve öneriler. Kastamonu Eğitim Dergisi, 27(1), 175-185.

Büyüköztürk, Ş., Kılıç-Çakmak, E., Akgün, Ö. E., Karadeniz, Ş., \& Demirel, F. (2019). Eğitimde bilimsel araştırma yöntemleri (26. Baskı). Ankara: Pegem Akademi.

Caena, F. (2014). Teacher competence frameworks in Europe: Policy-as-discourse and policy-as-practice. European Journal of Education, 49(3), 311-331.

Can, E. (2019). Öğretmenlerin mesleki gelişimleri: Engeller ve öneriler. Eğitimde Nitel Araştırmalar Dergisi, 7(4), 1618-1650. doi: 10.14689/Issn.2148-2624.1.7c.4s.14m

Can, N., Yıldırım, N., Bedir, G., \& Atalmış, E. H. (2019). İdealist öğretmen ölçeğinin geliştirilmesi: Geçerlik ve güvenirlik çalışması. Celal Bayar Üniversitesi Sosyal Bilimler Dergisi, 17(4), 405-418. doi: $10.18026 /$ cbayarsos.628634

Cerit, Y. (2008). Öğretmen kavramı ile ilgili metaforlara ilişkin öğrenci, öğretmen ve yöneticilerin görüşleri. Türk Eğitim Bilimleri Dergisi, 6(4), 693-712.

Creswell, J. W. (2020). Nitel araştırma yöntemleri, beş yaklaşıma göre nitel araştırma ve araştırma deseni. ( 5. baskı, Çev. M. Bütün, ve S. B. Demir). Ankara: Siyasal Kitabevi

Çeküç, S. (2008). Lider öğretmen yeterliliklerinin incelenmesi üzerine empirik bir araştırma (Yayımlanmamış yüksek lisans tezi). Marmara Üniversitesi Eğitim Bilimleri Enstitüsü, İstanbul.

Çelikten, M., \& Can, N. (2003). Yönetici, öğretmen ve veli gözüyle ideal öğretmen. Selçuk Üniversitesi Eğitim Fakültesi Dergisi, 15, 253-267.

Çelikten, M., Şanal, M., \& Yeni, Y. (2005). Öğretmenlik mesleği ve özellikleri. Erciyes Üniversitesi Sosyal Bilimler Enstitüsü Dergisi, 19(2), 207-237.

Çetin, A., \& Aydın, S. (2019). Liselerin pansiyonunda nöbetçi öğretmen olmak: Sorunlar ve çözüm önerileri. Gazi Üniversitesi Eğitim Fakültesi Dergisi, 39(3), 1797-1825.

Çetin, A., \& Sadık, F. (2020). Özel dershanelerden resmi okullara atanan fen bilimleri öğretmenlerinin mesleki yeterlik algıları ve davranışlarının incelenmesi. Kırşehir Eğitim Fakültesi Dergisi, 21(1), 456- 503.

Çetin, A., \& Ünsal, S. (2020). Öğretmen algılarına göre fark oluşturan öğretmen. İnsan ve Toplum Dergisi, 10(2). 35-64. doi: 10.12658/M0331

Çolak, ì., \& Altınkurt, Y. (2017). Okul iklimi ile öğretmenlerin özerklik davranışları arasındaki ilişki. Kuram ve Uygulamada Eğitim Yönetimi, 23(1), 33-71. doi: 10.14527/kuey.2017.002

Dekker-Groen, A. M., van der Schaaf, M. F., \& Stokking, K. M. (2013). A teacher competence development programme for supporting students' reflection skills. Teachers andTeaching: Theory and Practice, 19(2), 150-171. doi: 10.1080/13540602.2013.741837

Demir, M. K., \& Arı, E. (2013). Öğretmen sorunları - Çanakkale ili örneği. On Dokuz Mayıs Üniversitesi Eğitim Fakültesi Dergisi, 32(1), 107-126.

Ekinci, N. (2017). Öğretmen adaylarının öğretmenlik mesleği ve alan seçiminde etkili olan motivasyonel etkenler. ElementaryEducation Online, 16(2), 394-405. doi: 10.17051/ilkonline.2017.304706

Elçiçek, Z., \& Yaşar, M. (2016). Türkiye'de ve dünyada öğretmenlerin mesleki gelişimi. Elektronik Eğitim Bilimleri Dergisi, 5(9), 12-19.

Eroğlu, M., \& Özbek, R. (2020). Etkili öğretmenlerin mesleki gelişimi. Dicle Üniversitesi Ziya Gökalp Eğitim Fakültesi Dergisi, 1(37), 73-92. doi: http://dx.doi.org/10.14582/DUZGEF.2020.142

Ertürk, R. (2016). Öğretmenlerin iş motivasyonları. Eğitim Kuram ve Uygulama Araştırmaları Dergisi, 2(3), 1-15.

Erzen, Z., \& Epçaçan, C. (2018). Öğretmen görüşlerine göre öğretmenlerin toplumdaki saygınlığının incelenmesi. Journal of Institute of Economic Development and Social Researches, 4(9), 331-345.

Gençtürk, E., Akbaş, Y., \& Kaymakçı, S. (2012). Sosyal bilgiler öğretmen adaylarının bakış açısıyla ideal öğretmenin özellikleri. Kuram ve Uygulamada Eğitim Bilimleri, 12(2), 1559-1572.

Goleman, D. (2011). Duygusal zekâ, EQ neden IQ'dan daha önemlidir? (Çev. B. S. Yüksel). İstanbul: Varlık Yayınları.

Göker, S. D., \& Gündüz, Y. (2017). Dünya ölçeğinde öğretmenlerin saygınlık statüsü ve özlük hakları. Milli Eğitim Dergisi, 46(213), 177-196. Erişim adresi: https://dergipark.org.tr/tr/download/article-file/441217

Gönülaçar, Ş. (2016). Türkiye'de öğretmen imajı ve itibarı üzerine bir inceleme. Erişim adresi: https://www.academia.edu/20607351/T\%C3\%BCrkiye_de_\%C3\%96\%C4\%9Fretmen_\%C4\%B0maj\%C4\%B1_ ve_\%C4\%B0tibar\%C4\%B1_\%C3\%9Czerine_Bir_\%C4\%B0nceleme

Gültekin, M. (2015). İlköğretim öğrencilerinin ideal öğretmen algısı. Electronic Turkish Studies, 10(11), 725-756. doi: http://dx.doi.org/10.7827/TurkishStudies.8624

Hargreaves, L. (2009). The status and prestige of teacher sand teaching. In L. J. Saha, \& A. G. Dworkin (Eds.), International handbook of research on teacher sand teaching 21(1), 217-229. New York: Springer

Hatipoğlu, A., \& Kavas, E. (2016). Veli yaklaşımlarının öğretmen performansına etkisi. Insan ve Toplum Bilimleri Araştırmaları Dergisi, 5(4), 1012-1034.

Hoyle, E. (2001). Teaching: Prestige, status and esteem. Educational Management and Administration, 29(2), 139152. 
Işıktaş, S. (2015). Öğretmen adaylarının iyi öğretmen olma ile ilgili görüşleri. Hacettepe Üniversitesi Eğitim Fakültesi Dergisi, 30(4), 119-131.

Illğan, A., \& Ceviz, H. (2019). There lation ship between the perception of the society related to teaching profession and teachers' Professional motivation according to teachers view. Kuram ve Uygulamada Eğitim Yönetimi, 25(2), 285-338. doi: 10.14527/kuey.2019.008.

İsmayılov, Ü. (2019). Öğretmenlerin duygusal zekâlarının örgütsel güvene etkisi (Yayımlanmamış yüksek lisans tezi). Necmettin Erbakan Üniversitesi Eğitim Bilimleri Enstitüsü, Konya.

Kahyaoğlu, R. B., \& Karataş, S. (2019). Mesleki gelişim eğitim seminerlerine ilişkin öğretmen görüşleri. Pamukkale Üniversitesi Sosyal Bilimler Enstitüsü Dergisi, 37, 191-220. doi: 10.30794/pausbed.536050

Karadoğan, A. (2019). Z kuşağı ve öğretmenlik mesleği. Ağrı Ibrahim Çeçen Üniversitesi Sosyal Bilimler Enstitüsü Dergisi, 5(2), 9-42. doi: 10.31463/aicusbed.597636

Karaman, M., Acar, A., Kılıç, O., Buluş, U., \& Erdoğan, Ö. (2013). Sakarya ilinde görev yapan öğretmenlerin gözüyle öğretmenlik mesleğinin statüsü ve saygınlığı. VI. Ulusal Lisansüstü Eğitim Sempozyumu Bildiriler Kitabı(ss. 104-110). Sakarya: Sakarya Üniversitesi.

Kızıltepe, Z. (2002). İyi ve etkili öğretmen. Eğitim ve Bilim Dergisi, 27(126), 10-14.

Koşar, D. (2019). Öğretmenlerin mesleki deneyimlerinin incelenmesi: Öğretmen olmanın anlamına ilişkin fenomenolojik bir çalışma. Tarih Kültür ve Sanat Araştırmaları Dergisi 8(2), 333-346. doi: 10.7596/taksad.v8i2.2122

Kozikoğlu, İ., \& Özcanlı, N. (2020). Öğretmenlerin 21. yüzyıl öğreten becerileri ile mesleğe adanmışlıkları arasındaki ilişki. Cumhuriyet International Journal of Education, 9(1), 270-290. doi: http://dx.doi.org/10.30703/cije.579925

Kozikoğlu, İ., \& Senemoğlu, N. (2018). Mesleğe yeni başlayan öğretmenlerin karşılaştıkları güçlükler: Nitel bir çözümleme. Eğitimde Nitel Araştırmalar Dergisi, 6(3), 341-371. doi:10.14689/issn.2148-2624.1.6c3s16m

Lincoln, Y. S., \& Guba, E. G. (1985). Naturalisticinquiry. California: SAGE.

Merriam, S. B. (2013). Nitel araştırma desen ve uygulama için bir rehber. (Çev. S. Turan). Ankara: Nobel Akademik Yayıncilık

Milli Eğitim Bakanlığı, (2017). Öğretmenlik Mesleği Genel Yeterlikleri. Ankara Öğretmen Yetiştirme ve Geliştirme Genel Müdürlüğü, (2019). Genelge (27.05.2019). Sayı: 2019/8.

Özdemir Şerbet, T. O. (2012). Okul müdürleri ve öğretmenlerin etkili öğretmen niteliklerine ilişkin algıları (Zeytinburnu-Bakırköy örneği) (Yayımlanmamış yüksek lisans tezi). Yıldız Teknik Üniversitesi Sosyal Bilimler Enstitüsü, İstanbul.

Özkan, Y. (2017). Fen bilgisi ve sınıf öğretmen adaylarının öğretmenlik mesleğine yönelik tutumlarının incelenmesi (Yayımlanmamış yüksek lisans tezi). Akdeniz Üniversitesi Eğitim Bilimleri Enstitüsü, Antalya.

Özkan, M., \& Arslantaş, İ. (2013). Etkili öğretmen özellikleri üzerine sıralama yöntemiyle bir ölçekleme çalışması. Trakya Üniversitesi Sosyal Bilimler Dergisi, 15(1), 311-330.

Patton, M. Q. (2014). Nitel araştırma ve değerlendirme yöntemleri. (Çev. M. Bütün ve S. B. Demir). Ankara: Pegem Akademi.

Sakız, G. (2016). Etkili öğretmenlik ve öğretmen niteliğinin geliştirilmesi. Kuramsal Eğitimbilim Dergisi, 9(2), 214244. doi: http://dx.doi.org/10.5578/keg.10451

Sarıbaş, S., \& Babadağ, G. (2015). Temel eğitimin temel sorunları. Anadolu Eğitim Liderliği ve Öğretim Dergisi, 3(1), 18-34.

Sarıtaş, S. (2013). Ortaöğretim öğrencilerine göre ideal öğretmen özellikleri (Yayımlanmamış yüksek lisans tezi), Gazi Üniversitesi Eğitim Bilimleri Enstitüsü, Ankara.

Sezer, Ş. (2018). Öğretmenlerin sınıf yönetimi tutumlarının öğrencilerin gelişimi üzerindeki etkileri: Fenomenolojik bir çözümleme. Hacettepe Üniversitesi Eğitim Fakültesi Dergisi, 33(2), 534-549. doi: 10.16986/HUJE.2017031319

Söylemez, R. (2018). Yüksek lisans düzeyindeki sosyal bilgiler eğitimcilerinin ideal öğretmen algısı (Yayımlanmamış yüksek lisans tezi). İnönü Üniversitesi Eğitim Bilimleri Enstitüsü, Malatya.

Şahin, A. (2011). Öğretmen algılarına göre etkili öğretmen davranışları. Ahi Evran Üniversitesi Eğitim Fakültesi Dergisi, 12(1), 239-259.

Şimşek, C., \& Tuzluca, S. (2015). Yetişkinlerin düşünce hayatında olumlu iz bırakan öğretmenlerin ortak kişilik ve davranış özellikleri. Eğitim ve Öğretim Araştırmaları Dergisi, 4(3), 131-141.

Şişman, M. (2011). Eğitimde mükemmellik arayışı, Etkili okullar. Ankara: Pegem Akademi.

Taşkaya, S. M. (2012). Nitelikli bir öğretmende bulunması gereken özelliklerin öğretmen adaylarının görüşlerine göre incelenmesi. Erciyes Üniversitesi Sosyal Bilimler Enstitüsü Dergisi, 1(33), 283-298.

Tatlı, Z. (2016). Proje geliştirme sürecine dair öğretmen görüşleri. Yüzüncü Yıl Üniversitesi Eğitim Fakültesi Dergisi, 13(1), 631-656.

TEDMEM, (2014). Öğretmen gözüyle öğretmenlik mesleği. Ankara: Rapor dizisi 3.

Toprakçı, E. (2009) Öğretmenlerin Suç Karnesi- Yargı Kararlı Gazete Haberleri Ölçütünde Karşılaştırmalı Bir Analiz Denizli: Pamukkale Üniversitesi Eğitim Fakültesi, IV.Ulusal Eğitim Yönetimi Kongresi, Bildiri Kitabı, 14-15 
Mayıs 2009 (ss.475-487) Erişim: https://www.erdaltoprakci.com.tr/wp-content/uploads/2020/05/suckarnesi.pdf

Toprakçı, E., E.Bozpolat ve S.Buldur (2010) Öğretmen Davranışlarının Kamu Meslek Etiği İlkelerine Uygunluğu e international journal of educational research Volume: 1 Issue: 2 Autumn 2010 pp..35 50.

Erişim: http://static.dergipark.org.tr/article-download/imported/1073000034/1073000025.pdf?

Turhan, M., Demirli, C., \& Nazik, G. (2012). Sınıf öğretmenlerinin mesleğe adanmışlık düzeyine etki eden faktörler: Elazığ örneği. İstanbul Ticaret Üniversitesi Sosyal Bilimler Dergisi, 11(21), 179-192.

Ulusoy, M. (2013). Sınıf öğretmeni adaylarının ideal öğretmen ve mesleki yeterliklerle ilgili değerlendirmeleri. Uşak Üniversitesi Sosyal Bilimler Dergisi, 6(4), 324-341.

Ulutaş, P. (2017). Öğretmenlerin bakış açısından öğretmenlik mesleğinin toplumsal statüsü (Yayımlanmamış yüksek lisans tezi). Mersin Üniversitesi Eğitim Bilimleri Enstitüsü, Mersin.

Ünsal, S., \& Bağçeci, B. (2016). Öğretmenlerin mesleki imajlarına ilişkin görüşleri ve mesleki imaja etki eden faktörler. Journal of Human Sciences, 13(3), 3905-3926. doi: 10.14687/jhs.v13i3.3908

Yıldııım, N., \& Öner, S. (2016). Etkili/başarılı sınıf öğretmenleri üzerine nitel bir analiz. Ahi Evran Üniversitesi Kırşehir Eğitim Fakültesi Dergisi (KEFAD), 17(3), 135-155.

Yıldırım, A., \& Şimşek, H. (2011). Sosyal bilimlerde nitel araştırma yöntemleri. Ankara: Seçkin Yayıncılık

Yıldız, A., \& Ünlü, D. (2013). Metaforlarla öğretmenliğin dönüşümü: "Dün heybetli bir şelaleydik, bugün ise kurumaya yüz tutmuş dere". III. Uluslararası Eleştirel Eğitim Konferansı'nda sunulmuş sözlü bildiri. Ankara: Ankara Üniversitesi.

Yirci, R. (2017). Öğretmen profesyonelliğinin önündeki engeller ve çözüm önerileri. Ahi Evran Üniversitesi Kırşehir Eğitim Fakültesi Dergisi (KEFAD), 18(1), 503-522. 
Teachers of the Year:

\section{Their Studies, Motivation Elements, Personal and Professional Features}

\author{
Assoc. Prof. Dr. Serkan Ünsal \\ Kahramanmaraş Sütçü Imam University-Turkey \\ serkan-unsal09@hotmail.com
}

\author{
Hasan İ̆ge (M.A.) \\ Kahramanmaraş Sütçü Imam University-Turkey \\ hasanigde46@gmail.com
}

\begin{abstract}
This study aims to identify the studies, motivational factors, personal and professional characteristics of the teachers of the year, and the reflection of their choice as the teacher of the year on their professional and social lives within the framework of their own experiences. Having a qualitative research pattern, this study used a phenomenological design. The working group of the study consisted of eight teachers who were selected as the teacher of the year in a province of TURKEY. These teachers were determined in accordance with the criterion sampling method. The criterion was to be chosen as the teacher of the year. The data were gathered through use of a semi-structured interview form. Content and descriptive analyzes were used during data analysis. In the research, it was found that the teachers of the year had personal characteristics such as being sensitive to social problems, empathy, giving importance to sincerity, loving children, being tolerant and curious; It has been concluded that the student has professional characteristics such as touching her life, being altruistic, loving his / her profession, sparing time outside of school, loving the lesson, leading, professional autonomy, and giving importance to professional development. Also, in the research, it was concluded that the teachers of the year did many academic, social, cultural and sportive activities.
\end{abstract}

Keywords: Teacher, Teaching profession Teacher's influence, Teacher of the year

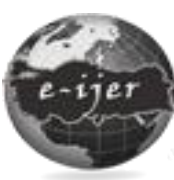

E-International Journal of Educational Research, Vol: 12, No: 1, 2021, pp. 68-88

DOI: 10.19160/ijer.818654

\section{Suggested Citation:}

Ünsal, S., \& İğde, H. (2021). Teachers of the Year: Their Studies, Motivation Elements, Personal and Professional Features, E-International Journal of Educational Research, Vol: 12, No: 1, 2021, pp. 68-88, DOI: 10.19160/ijer.818654 


\section{EXTENDED ABSTRACT}

Problem: Although the teachers of the year are determined depending the criteria specified each year by the Ministry of National Education, few studies were available in the related literature addressing the teachers of the year. Eroglu and Özbek (2020) examined the teachers of the year in terms of their professional development. A very limited number of studies have been conducted since 2012 regarding the teachers of the year selected regularly in each province. This was considered as a shortcoming by the researchers and that this study is expected to contribute to the relevant literature. Considering that training qualified teachers has become an increasingly significant issue in each society (Caena, 2014; Dekker-Groen, Marieke, van der Schaaf, \& Stokking, 2013), this study will provide important data for the universities responsible for raising qualified teachers and decision makers. In addition, the elicited data will be a guide for teachers who are in an effort and search to make their profession better. In line with the aforementioned significance, this study aims to identify the studies, motivational factors, personal and professional characteristics of the teachers of the year, and the reflection of their choice as the teacher of the year on their professional and social lives within the framework of their own experiences.

Answers to the following questions were sought;

1. What are the personal characteristics of theteachers of the year?

2. What are the professional characteristics of the teachers of the year?

3. What studies did the teachers of the year conduct?

4. What are the factors motivating the teachers of the year?

5. What are the implications of being a teacher of the year in professional and social life?

6. What are the common characteristics of the teachers of the year?

Method: Having a qualitative research pattern, this study used a phenomenological design. The phenomenon in this study was to be "the teacher of the year". The study deployed a criterion sampling method, one of the purposive sampling methods, in order to reach a rich data set and explain the phenomenon in the best way (Büyüköztürk et al., 2019). The criterion determined for the working group was to be the teacher of the year. In accordance with the aim and criteria of the research, theworking group of the research consisted of eight teachers who were determined as the teachers of the year in different years between 2012 and 2019 by Kahramanmaraş Provincial Directorate of National Education. Interview technique was used as a data collection tool. A semistructured "Teachers of the Year Interview Form (TYIF)" developed by the researchers was used during data collection process. The relevant literature was examined while preparing the form (Akçadağ, 2017; Çetin, \& Ünsal, 2020; Ylldırım, \& Öner, 2016) and two experts from the Faculty of Education of Kahramanmaraş Sütçü Imam University were consulted.Both content and descriptive analyzes were made during data analysis. Descriptive analysis was conducted on the data obtained from the question of what the professional characteristics of the teachers of the yearare. Content analysis was performed for the data obtained from the other research questions. Merriam (2013) emphasized that the research be carried out in an ethical manner for the purpose of ensuring validity and reliability in qualitative studies. Ethical rules were followed to ensure validity and reliability in the present study.

Findings: This study aims to identify the studies, motivational factors, personal and professional characteristics of the teachers of the year, and the reflection of their choice as the teacher of the year on their professional and social lives within the framework of their own experiences.

The findings revealed that the teachers of the year had professional autonomy. This may be due to the teachers' willingness to use autonomy in general (Çolak, \& Altınkurt, 2017). Although teacher autonomy is rather limited in Turkey (Bümen, 2019), the teachers of the year were found to beprone to professional autonomy. This may result from the fact that they had high level of selfefficacy perceptions and that they had positive results from the studies they conducted by exhibiting professional characteristics. 
It is among the professional characteristics of the teachers of the year to cooperate with parents. As an important stakeholder in education, parents should have a role in supporting teachers' success in many activities. The way to achieve this is to use collaborative communication. In this regard, teachers of the year may have cooperated with parents in order to receive parents' support in their activities. Besides, parents'cooperation contributes positively to the students in various ways (Aslanargun, 2007). These contributions are; increasing their commitment to the school, enhancing academic achievement, fulfilling their responsibilities, participating in classroom activities, completing homework and developing positive behaviors. The findings also suggested that the teachers of the year attached importance to their professional development. Despite the obstacles (Can, 2019; Yirci, 2017), inadequacies (Çetin ve Sadık, 2020), activities' lack inmeeting the needs (Elçiçek, \& Yaşar, 2016), and being non-functional in the current form (Kahyaoğlu, \& Karataş, 2019), that the teachers of the year improved themselves by attaching significance to their professional development is a remarkable result of the study. This result may be due to the fact that the teachers of the year were aware of the importance of their professional development and liked the profession (Eroğlu, \& Özbek, 2020).

As a result of the study, teachers of the year were identified to have strong communication, establish empathy and take note of sincerity among their personal characteristics. This result was in line with that of the one conducted by Başaran and Baysal (2016) on ideal teachers.

Another result of the study showed that being the teacher of the year increased the prestige of teachers. The research results that teachers' reputation in society is gradually decreasing (Can, 2019; Demir, \& Arl, 2013; TEDMEM; 2014; Yıldız, \& Ünlü, 2013) and that they do not get enough dignity that their profession deserves (Toprakçı, 2009; Karaman, Acar, Kıllç, Buluş, \& Erdoğan, 2013) differ with those of this study. This differentiation has a consistency in itself. The teachers'competency and quality are considered to be the factors that determine the prestige of teaching (Bozbayındır, 2019; Hargreaves, 2009; Hoyle, 2001; Ulutaş; 2017). In other words, teachers' competency and quality in their profession have positive reflectionson the dignity of the profession. The teachers were selected as the teachers of the year depending upon their studies and their success in terms of professional characteristics, teacher qualification and competency. Being the teachers of the year is a striking result in terms of the contribution of teachers to increasing the prestige of the profession and revealing the significance of teacher quality and competency in increasing the dignity of the profession.

Suggestions: During the process of determining the teachers of the year, it may be recommended to adopt an approach in which more teachers can be included in the evaluation process by encouraging them to include all in the province in the sequential evaluations made by decision makers in the provincial organization of the Ministry of National Education. In this way, the selection of the teachers of the year from the same and similar branches may be prevented.

Studies may be conducted on the similarities and differences of the teachers of the year with other teacher conceptualizations such as the ideal teacher, the teacher making a difference, and the leader teacher; moreover, various studies can also be carried out to analyze the difficulties faced by the teachers of the year, the strategies to overcome these difficulties, the working systematics and the effects on the prestige of the profession. The findings are limited to the data collected from the participants in this regard. Similar studies may be conducted with richer data sets that examine the teachers of the year from different perspectives by using different research models and data collection tools. 